\title{
PROGRAMI OSNAŽIVANJA DJECE S TEŠKOĆAMA U RAZVOJU I MLADIH S INVALIDITETOM U MREŽI KNJIŽNICE MARINA DRŽIĆA U ZAGREBU
}

\author{
PROGRAMS FOR EMPOWERING \\ THE CHILDREN WITH DEVELOPMENTAL DISABILITIES \\ AND YOUTH WITH DISABILITIES IN THE MARIN DRŽIĆ \\ LIBRARY NETWORK IN ZAGREB
}

Snježana Ercegovac

Knjižnice grada Zagreba

snjezana.ercegovac@kgz.hr

Ana Pavlek

Knjižnice grada Zagreba

ana.pavlek@kgz.hr

\author{
UDK / UDC 027.022-053.4- \\ 056.36(497.5 Zagreb):159.9:37 \\ Stručni rad / Professional paper \\ Primljeno / Received: 31. 10. 2018. \\ Prihvaćeno / Accepted: 24. 12. 2018.
}

\section{Sažetak}

Cilj. U radu se donosi pregled programa namijenjenih djeci s teškoćama u razvoju i mladima s invaliditetom, kao i djeci s teškoćama čitanja i disleksijom koji se provode u Dječjoj knjižnici Marina Držića i Knjižnici Savica, dvama ograncima mreže Knjižnice Marina Držića, knjižnice u mreži Knjižnica grada Zagreba.

Metodologija. Kronološkim slijedom opisuju se programi koji se provode u sklopu projekta Knjižnica širom otvorenih vrata, među kojima se ističu programi čitanja u društvu pasa pomagača, ciklus psiholoških i pedagoških radionica $D a$, mogu! te ciklus pričaonica Možemo i mi!, kao i niz logopedskih predavanja i radionica koji se provodi u okviru nacionalne kampanje I ja želim čitati!

Rezultati. Pregled programa u sklopu projekta Knjižnica širom otvorenih vrata pokazuje da kontinuirane i sustavne suradnje na planiranju i realizaciji inkluzivnih knjiž-

Vjesnik bibliotekara Hrvatske 61, 2(2018), 257-285

ISSN 0507-1925

(C) VBH 2018. 
ničnih programa pridonose osnaživanju i pozitivnim pomacima u općem razvoju djece $\mathrm{s}$ teškoćama u razvoju i mladih $\mathrm{s}$ invaliditetom, rezultiraju obogaćenim i poboljšanim programom te potiču inkluzivno obrazovanje i osposobljavanje. Informiranjem o teškoćama čitanja i disleksiji na lokalnoj se razini pridonosi educiranju i senzibiliziranju javnosti za problematiku osoba s teškoćama čitanja i disleksijom.

Originalnost/vrijednost. Prvi sustavan prikaz inkluzivnih programa za djecu s teškoćama u razvoju i mlade s invaliditetom koji se provode u Dječjoj knjižnici Marina Držića i Knjižnici Savica koji može poslužiti kao poticaj za provođenje sličnih programa posvećenih toj osjetljivoj korisničkoj skupini.

Ključne riječi: čitanje u društvu pasa pomagača, disleksija, inkluzivni knjižnični programi za djecu s teškoćama u razvoju i mlade s invaliditetom, teškoće čitanja

\begin{abstract}
Purpose. This paper presents an overview of the programs intended for the children with developmental disabilities and youth with disabilities, as well as for the children with reading disorders and dyslexia, which are carried out at the Marin Držić Children's Library and the Savica Library, two branches of the Marin Držić Library network, within the Zagreb City Libraries network.
\end{abstract}

Methodology. The programs which are carried out through the Library Doors Wide Open project are described chronologically. Among these, the most prominent are the programs of reading in the company of assistance dogs, a series of psychological and pedagogical workshops Yes, I can!, a series of storytelling workshops So can we!, as well as a number of logopedics lectures and workshops organized within the national campaign I Want to Read Too!

Findings. The overview of the programs in the Library Doors Wide Open project demonstrates that the continuous and systematic collaborations in planning and realization of the inclusive library programs contribute greatly to the empowerment and a positive shift in the general development of the children with developmental disabilities and youth with disabilities. Additionally, they result in enriched and enhanced programs, and encourage inclusive education and training. Informing the public about reading disorders and dyslexia contributes to the education and sensitizing of the local community to the issues and problems faced by the people with reading disorders and dyslexia.

Originality/value. This is the first systematic overview of the inclusive programs for children with developmental disabilities and youth with disabilities run in the Marin Držić Children's Library and the Savica Library which can serve as an incentive for organizing similar programs dedicated to this sensitive user group.

Keywords: dyslexia, inclusive library programs for children with developmental disabilities and youth with disabilities, reading in the company of assistance dogs, reading disorders 


\section{Uvod}

Posvećenost međunarodne zajednice izgradnji društava u kojima se inkluzija djece s teškoćama u razvoju sve više prihvaća rezultirala je poboljšanjem položaja te djece i njihovih obitelji. ${ }^{1}$ Svojom obvezom podržavanja Konvencije o pravima djeteta $^{2}$ i Konvencije o pravima osoba s invaliditetom ${ }^{3}$ Vlada Republike Hrvatske, poput drugih vlada širom svijeta, obvezala se da svoj djeci, bez obzira na sposobnost ili teškoće u razvoju, bez diskriminacije osigura uživanje u pravima koja im pripadaju. Te dvije konvencije svjedoče o sve snažnijem svjetskom pokretu posvećenom inkluziji djece s teškoćama u razvoju u život zajednice. U njima se ističe da djeca s teškoćama u razvoju imaju ista prava kao i sva druga djeca te zahtijevaju priznavanje svakog djeteta kao punopravnog člana svoje obitelji, zajednice i društva. Jedno od tih prava jest i pravo na obrazovanje. Budući da inkluzivno obrazovanje zahtijeva resurse izvan učionice, partnerstva s civilnim društvom poticajan su primjer za poboljšanje nastavnog procesa u koji su uključena djeca s teškoćama u razvoju. ${ }^{4}$

U preporukama Europske agencije za posebne potrebe i uključivo obrazovanje $\mathrm{s}^{5}$, kao i u strateškom dokumentu Europska strategija za osobe s invaliditetom (2010. - 2020. $)^{6}$ napose se ističe važnost poboljšanja obrazovne politike i prakse za učenike s invaliditetom i posebnim obrazovnim potrebama. Programi koji se opisuju u ovom članku rezultat su knjižničarskih nastojanja da se nadopuni i obogati odgojno-obrazovni program za djecu s teškoćama u razvoju i mlade s invaliditetom te na taj način pridonese poboljšanju njihova položaja.

Spomenuti knjižnični programi nadovezuju se i na Agendu Ujedinjenih naroda za održivi razvoj 2030., posebice na njezina dva cilja - četvrti i deseti. Četvrti cilj odnosi se na uključivo i kvalitetno obrazovanje i u njemu se govori o jednakom pristupu svim razinama obrazovanja i stručnoj obuci za ranjive skupine, u koje se ubrajaju osobe s invaliditetom i djeca u ranjivom položaju. ${ }^{7}$ Deseti cilj odnosi se na smanjenje nejednakosti unutar država i između njih te se u njemu navodi da

1 Usp. UNICEF. Stanje djece u svijetu 2013: djeca s teškoćama u razvoju. [citirano: 2018-0909]. Dostupno na: https://www.unicef.hr/wp-content/uploads/2015/09/Djeca_s_teskocama_ HR_6_13_w.pdf.

2 Konvencija o pravima djeteta. [citirano: 2018-09-09]. Dostupno na: https://www.unicef.hr/ wp-content/uploads/2017/05/Konvencija_20o_20pravima_20djeteta_full.pdf.

3 Konvencija o pravima osoba s invaliditetom. // Narodne novine 6, 80(2007). [citirano: 201809-09]. Dostupno na: https://narodne-novine.nn.hr/clanci/medunarodni/2007_06_6_80.html.

4 Usp. UNICEF. Nav. dj., str. 10.

5 Europska agencija za posebne potrebe i uključivo obrazovanje - publikacije na hrvatskom. [citirano: 2018-09-09]. Dostupno na: https://www.european-agency.org/about-us.

6 Dokument koji određuje smjer djelovanja za osnaživanje osoba s invaliditetom kako bi mogle u potpunosti uživati svoja prava i ravnopravno s drugima sudjelovati u društvu i gospodarstvu. Usp. Europska strategija za osobe s invaliditetom (2010. - 2020.). [citirano: 2018-09-09]. Dostupno na: http://www.soih.hr/pdf/europska-strategija-za-osobe-s-invaliditetom.pdf.

7 Usp. Globalni ciljevi održivog razvoja do 2030. [citirano: 2018-09-09]. Dostupno na: http:// odraz.hr/media/291518/globalni\%20ciljevi\%20odrzivog\%20razvoja\%20do\%202030_web.pdf. 
bi, radi smanjenja nejednakosti, javne politike trebale voditi računa o potrebama ugrožene i marginalizirane populacije. Također se ističe važnost osnaživanja i promoviranja socijalne, gospodarske i političke uključenosti svih, neovisno o starosti, spolu, invalidnosti, rasi, etničkoj pripadnosti, podrijetlu, religiji te gospodarskom ili drugom statusu. ${ }^{8}$

Temeljni strateški dokument posvećen borbi protiv siromaštva i socijalne isključenosti u Republici Hrvatskoj ${ }^{9}$ trebao bi svim relevantnim dionicima omogućiti sustavan i zajednički pristup rješavanju problema siromaštva i socijalne isključenosti. Europska komisija definirala je socijalnu isključenost kao proces koji pojedince gura na margine društva i sprečava ih da, zbog osobnog siromaštva, nedostatka osnovnih kompetencija i mogućnosti za cjeloživotno učenje ili zbog diskriminacije, sudjeluju u životu zajednice i društvenim zbivanjima s osjećajem osobnog dostojanstva. U dokumentu se navodi da su socijalnoj isključenosti izložene i osobe s invaliditetom koje čine više od $12 \%$ ukupnog stanovništva Republike Hrvatske i koje se razlikuju s obzirom na vrstu (osobe s tjelesnim i senzoričkim invaliditetom te osobe $\mathrm{s}$ mentalnim/intelektualnim teškoćama) i stupanj invalidnosti, a da su, što se tiče socijalne isključenosti, najugroženija skupina djeca s teškoćama u razvoju.

Svoj doprinos smanjenju socijalne isključenosti i ublažavanju posljedica siromaštva razvijanjem inkluzivnih usluga za osnaživanje djece s teškoćama u razvoju i mladih s invaliditetom daju i Knjižnice grada Zagreba (KGZ) koje neprekidno nastoje poboljšati svoje programe i usluge posvećene najosjetljivijim društvenim skupinama, što je i dio Strateškog plana Knjižnica grada Zagreba. ${ }^{10} \mathrm{U}$ njemu se navodi da KGZ, u skladu s nacionalnim i međunarodnim dokumentima, provodi niz programa kojima se nastoji pridonijeti poboljšanju kvalitete života i socijalne integracije djece s teškoćama u razvoju te mladih i odraslih osoba s invaliditetom. U njemu se također ističe da će Knjižnice grada Zagreba i nadalje inicirati i osmišljavati različite programe za poticanje razvoja kreativnosti i usvajanja novih vještina i znanja te na taj način pridonositi aktivnom uključivanju pripadnika tih skupina u kulturna i društvena zbivanja, kao i prepoznavanju knjižnice kao mjesta zadovoljavanja potreba za informiranjem, kulturom, razonodom, obrazovanjem i druženjem.

Dio tih nastojanja ostvaruje se i projektom Knjižnica širom otvorenih vrata, pokrenutim 2007. godine. U tom projektu od samog početka sudjeluju Dječja knjižnica Marina Držića i Knjižnica Savica, ogranci Knjižnice Marina Držića, knjižnice u mreži Knjižnica grada Zagreba. Obje se knjižnice nalaze u zagrebačkoj gradskoj četvrti Trnje u kojoj je smješteno nekoliko gradskih ustanova u kojima se provode programi rehabilitacije i obrazovanja djece s teškoćama u razvoju

\footnotetext{
8 Isto, str. 10-11.

9 Usp. Strategija borbe protiv siromaštva i socijalne isključenosti u Republici Hrvatskoj (2014. - 2020.) [citirano: 2018-09-09]. Dostupno na: https://www.vlada.hr/UserDocsImages//Sjednice/ Arhiva//148\%20-\%203.pdf.

10 Usp. Knjižnice grada Zagreba. Strateški plan 2014.-2020. [citirano: 2018-09-09]. Dostupno na: http://www.kgz.hr/hr/o-nama/misija-vizija-i-strategija/222.
} 
te mladih i odraslih osoba s invaliditetom, kao što su Poliklinika za rehabilitaciju slušanja i govora SUVAG, Udruga OZANA ${ }^{11}$, Osnovna škola Grigora Viteza i Dječji vrtić Vladimira Nazora. U suradnji s navedenim institucijama u tim se dvjema knjižnicama provode raznovrsni programi namijenjeni poticanju inkluzije ${ }^{12}$, a među njima ističu se programi čitanja u društvu pasa pomagača, osmišljeni kao pomoć djeci u poboljšanju čitanja i komunikacijskih vještina (osobito provedbom programa R.E.A.D. ${ }^{13}$ - engl. Reading Education Assistance Dogs) te ciklus psiholoških i pedagoških radionica $D a, m o g u$ ! i pričaonica Možemo $i$ mi! U sklopu nacionalne kampanje I ja želim čitati! $!^{14}$ čiji su supokretač Knjižnice grada Zagreba održavaju se logopedska predavanja s ciljem informiranja i senzibiliziranja javnosti u vezi s teškoćama čitanja i disleksijom, a organiziraju se i logopedske radionice za djecu.

\section{Programi za djecu s teškoćama u razvoju i mlade $s$ invaliditetom u Knjižnicama grada Zagreba}

\subsection{Projekt Knjižnica širom otvorenih vrata}

Knjižnice grada Zagreba u cilju poticanja čitanja, cjeloživotnog učenja i društvene inkluzije djece s teškoćama u razvoju te mladih i odraslih osoba s invaliditetom provode projekt Knjižnica širom otvorenih vrata. ${ }^{15}$

11 Udruga OZANA osnovana je 1991. godine radi poboljšanja kvalitete života osoba s invaliditetom i njihovih obitelji. Udruga trenutačno skrbi o desetero djece predškolske dobi s teškoćama u razvoju te o tridesetero mladih i odraslih osoba s invaliditetom unutar Centra OZANA, ustanove koju je Udruga osnovala 2002. godine. Pedagoški rad temelji se na načelima waldorfske pedagogije i prilagođava specifičnim potrebama korisnika, ovisno o njihovoj dobi te vrsti i stupnju teškoća u razvoju. Usp. Udruga Ozana. O nama. [citirano: 2018-09-21]. Dostupno na: http://www. udruga-ozana.hr/?page_id=2.

12 U skladu s IFLA-inim smjernicama za narodne knjižnice u kojima se ističe da usluge narodne knjižnice moraju biti dostupne svima, uključujući ljude s posebnim tjelesnim ili osjetilnim potrebama, kao i da su narodne knjižnice ustanove koje trebaju služiti dobrobiti lokalne zajednice i da se stoga njihove usluge trebaju temeljiti na potrebama te zajednice. Usp. IFLA-ine smjernice za narodne knjižnice. 2. hrv. izd. Zagreb: Hrvatsko knjižničarsko društvo, 2011. Str. 22-23.

13 Intermountain therapy animal - R.E.A.D. [citirano: 2018-09-24]. Dostupno na: http://www. therapyanimals.org/R.E.A.D.html.

14 I ja želim čitati - Nacionalna kampanja za osobe s teškoćama čitanja i disleksijom. [citirano: 2018-09-09]. Dostupno na: https://www.facebook.com/IJaZelimCitati/.

15 Kao temelj za osmišljavanje projekta poslužili su brojni dokumenti, poput UNESCO-ova Manifesta o narodnim knjižnicama (1994.), IFLA-ine izjave Knjižnice i intelektualna sloboda (1999.), Izjave o slobodnom pristupu informacijama Hrvatskoga knjižničarskog društva (2000.) i Etičkog kodeksa Hrvatskoga knjižničarskog društva donesenog 2002. godine. Program se temelji i na IFLA-inim smjernicama kao što su Narodna knjižnica: IFLA-ine i UNESCO-ove smjernice za razvoj službi i usluga (2003.), Smjernice za knjižnične usluge i usluge za gluhe (2004.), Smjernice za knjižnične službe i usluge za osobe s disleksijom (2004.), Knjižnice za slijepe u 
Aktivnosti namijenjene tim ranjivim skupinama provodile su se i prije, ali su 2007. objedinjene u projekt koji danas obuhvaća sljedeće programe:

- Igraonica - pričaonica - maštaonica program je namijenjen djeci starije predškolske i mlađe školske dobi s teškoćama sluha, govora, čitanja i pisanja, a uključuje i pomoć njihovim roditeljima, nastavnicima i odgojiteljima.

- Čitalački klub namijenjen je mladim i odraslim korisnicima s intelektualnim i tjelesnim invaliditetom.

- Kreativne radionice i kulturna događanja program su koji obuhvaća edukativne radionice (psihološke, radionice znakovnog jezika), likovne i kazališne radionice, izložbe, književne susrete, scenske predstave i tribine namijenjene djeci s teškoćama $u$ razvoju te mladima i odraslima $\mathrm{s}$ intelektualnim i tjelesnim invaliditetom.

- Upoznajmo glazbene instrumente program je posvećen glazbenim edukativnim susretima za slijepu i slabovidnu djecu i mladež.

- Izrada taktilnih slikovnica za slijepe i slabovidne.

- Kolektivni posjeti knjižnici obuhvaćaju posjete članova udruga i polaznika centara za djecu sa smetnjama u razvoju te mladih i odraslih s invaliditetom, a tu se ubrajaju i grupni posjeti korisnika knjižnice udrugama i ustanovama za osobe s posebnim potrebama.

- Volonterski rad osoba s posebnim potrebama ili invaliditetom u knjižnici.

Očekuje se da će projekt dugoročno toj skupini korisnika približiti knjižnicu kao mjesto za zadovoljavanje potreba za obrazovanjem, informiranjem, kulturom i razonodom, da će pridonijeti poboljšanju kvalitete njihova života i senzibilizirati javnost za postojanje i specifične potrebe slijepih i slabovidnih osoba, osoba s invaliditetom te osoba s problemima u govornoj komunikaciji, čitanju i pisanju. Projektom se želi ojačati tolerancija i uvažavanje različitosti, kao i integrirati osobe s posebnim potrebama u programe u kojima, zajedno s drugim korisnicima, stvaraju svijet uzajamnog pomaganja i osvješćivanja. ${ }^{16}$

Knjižnica Savica programe namijenjene djeci s teškoćama u razvoju i mladima s invaliditetom intenzivnije je počela provoditi uključenjem u projekt, dok su programi koji su se u Dječjoj knjižnici Marina Držića provodili prije pokretanja projekta poslužili kao jedno od njegovih ishodišta.

informacijsko doba (2005.) i Smjernice za građu laganu za čitanje (2005.). Usp. Čičko, H. Projekt „Knjižnica širom otvorenih vrata“. // Vjesnik bibliotekara Hrvatske 53, 2(2010), 10-14.

16 Usp. Knjižnice grada Zagreba - Knjižnica širom otvorenih vrata. [citirano: 2018-09-09]. Dostupno na: http://www.kgz.hr/hr/knjiznica-sirom-otvorenih-vrata-5993/5993. 


\subsubsection{Programi u Dječjoj knjižnici Marina Držića kao jedno od ishodišta pro- jekta Knjižnica širom otvorenih vrata}

U Dječjoj knjižnici Marina Držića i prije pokretanja opisanog projekta održavali su se programi za djecu s teškoćama u razvoju i mlade s invaliditetom, s naglaskom na grupnim posjetima i postavljanju izložaba u knjižničnoj Galeriji Vidrica. Tako je 2000. godine bila postavljena izložba radova učenika Centra Slava Raškaj. ${ }^{17}$ Godine 2002. u knjižnici je bila postavljena tematska izložba o disleksiji, a iste je godine tijekom Mjeseca hrvatske knjige na Interliberu, međunarodnom sajmu knjiga i učila, održana i kreativna radionica Igrom i pričom protiv disleksije. ${ }^{18}$ Pedeseta obljetnica osnivanja Osnovne škole Grigora Viteza 2003. godine obilježena je i u knjižnici izložbom radova učenika s teškoćama u razvoju. ${ }^{19}$

Korisnici Udruge OZANA 2004. godine u knjižnici su obilježili Dan glazbe uz glazbeni sastav Kraljevi ulice. ${ }^{20}$ Godine 2005. u knjižnici je bila postavljena izložba Ljeto korisnika Udruge OZANA koji su iste godine na Interliberu povodom obilježavanja Mjeseca hrvatske knjige održali kreativnu radionicu Govorimo i slušamo stihove. Iste je godine započela i suradnja s Dječjim vrtićem Vladimira Nazora te je ostvaren prvi grupni posjet knjižnici polaznika tog vrtića s teškoćama u razvoju. ${ }^{21}$

U 2006. godini u suradnji s Udrugom OZANA postavljena je najprije izložba Ptice, a zatim i izložba Crkve i dvorci Lijepe naše, dok su otvorenje te izložbe uveličali članovi glazbenog sastava Latino. Iste je godine postavljena izložba Rišemo pišemo - igrom do govorne komunikacije, izložba dječjih radova polaznika Poliklinike SUVAG, što je bio početak još jedne nove suradnje. Te je godine započela i suradnja s Udrugom roditelja djece s posebnim potrebama Put $u$ život $-P U Z ̌$ te je povodom Međunarodnog dana osoba s invaliditetom 3. prosinca u Galeriji Vidrica postavljena izložba Puž $i$ Vidrica na kojoj su bili izloženi dječji radovi nastali na kreativnim radionicama te udruge. ${ }^{22}$

Suradnja je nastavljena i sljedeće godine kada je knjižnicu posjetila grupa djece iz Poliklinike SUVAG, a povodom Dana državnosti i 480 godina glagoljske početnice, 21. lipnja 2007., svečano je otvorena izložba Slova stara, ali živa, na

\footnotetext{
17 Izvještaj Knjižnice Marina Držića za 2000. godinu. Arhiva Knjižnice Marina Držića. [interni dokument]

18 Izvještaj Knjižnice Marina Držića za 2002. godinu. Arhiva Knjižnice Marina Držića. [interni dokument]

19 Izvještaj Knjižnice Marina Držića za 2003. godinu. Arhiva Knjižnice Marina Držića. [interni dokument]

20 Izvještaj Knjižnice Marina Držića za 2004. godinu. Arhiva Knjižnice Marina Držića. [interni dokument]

21 Izvještaj Knjižnice Marina Držića za 2005. godinu. Arhiva Knjižnice Marina Držića. [interni dokument]

22 Izvještaj Knjižnice Marina Držića za 2006. godinu. Arhiva Knjižnice Marina Držića. [interni dokument]
} 
kojoj su izloženi likovni radovi korisnika Centra OZANA s motivima glagoljskih slova. ${ }^{23}$

Svi daljnji programi održani su u sklopu projekta Knjižnica širom otvorenih vrata.

\subsubsection{Knjižnica širom otvorenih vrata u Dječjoj knjižnici Marina Držića}

Dječja knjižnica Marina Držića organizirala je grupne posjete i povremena događanja za predškolce Dječjeg vrtića i školarce Osnovne škole Poliklinike SUVAG i prije uključenja u projekt Knjižnica širom otvorenih vrata, kao i nakon njegova pokretanja. U Dječjem vrtiću ${ }^{24}$ i Osnovnoj školi Poliklinike SUVAG ${ }^{25}$ provodi se odgojno-obrazovni i rehabilitacijski program za djecu s oštećenjima sluha i teškoćama u jezično-govornom razvoju.

Suradnja s Poliklinikom SUVAG intenzivirala se 2014. godine kada je započelo kontinuirano i sustavno organiziranje programa sa psima pomagačima, primarno namijenjenog djeci s teškoćama u razvoju.

Uvođenje spomenutog programa slično se odrazilo i na suradnju s Dječjim vrtićem Vladimira Nazora. Naime otada se redovnim grupama koje su najčešće dolazile u grupne posjete ili na određena događanja u knjižnicu priključuje i grupa djece s motoričkim oštećenjima za koju se u vrtiću organizira poseban program. ${ }^{26}$

Također, dok je do 2014. godine Dječja knjižnica Marina Držića više surađivala s mladima i odraslima s invaliditetom iz Centra OZANA, uvođenjem programa sa psima pomagačima počinje intenzivnija suradnja s odgojiteljima predškolske grupe Udruge OZANA. Udruga OZANA skrbi o desetero djece predškolske dobi $\mathrm{s}$ teškoćama u razvoju te tridesetero mladih i odraslih osoba s invaliditetom unutar Centra OZANA, ustanove koju je osnovala Udruga. Pedagoški rad u oba programa temelji se na načelima waldorfske pedagogije prilagođavajući se specifičnim potrebama korisnika uvjetovanih njihovom dobi te vrstom i stupnjem teškoća u razvoju, odnosno invaliditeta. ${ }^{27}$

Psi pomagači - udruga za intervenciju potpomognutu psima pomagačima ${ }^{28}$ te Udruga za pet therapy Indeficienter ${ }^{29}$ partneri su u planiranju i provođenju programa sa psima pomagačima u Dječjoj knjižnici Marina Držića.

23 Izvještaj Knjižnice Marina Držića za 2007. godinu. Arhiva Knjižnice Marina Držića. [interni dokument]

24 Dječji vrtić Poliklinike SUVAG. [citirano: 2018-09-21]. Dostupno na: http://www.suvag.hr/ djecji-vrtic-poliklinike-suvag/.

25 Osnovna škola Poliklinike SUVAG. [citirano: 2018-09-21]. Dostupno na: http://www.suvag. hr/osnovna-skola-poliklinike-suvag/.

26 Dječji vrtić Vladimira Nazora. Posebni program za djecu motoričkim oštećenjima (8-satni). [citirano: 2018-09-21]. Dostupno na: http://www.vrtic-vladimiranazora.zagreb.hr/default.aspx?id=57.

27 Udruga Ozana. Nav. dj.

28 Više informacija o udruzi Psi pomagači - udruga za intervenciju potpomognutu psima pomagačima dostupno je na stranici: https://www.psipomagaci.hr/.

29 Više informacija o Udruzi za pet therapy Indeficienter dostupno je na stranici: http://www. uptiv.hr/. 


\subsubsection{Suradnja Dječje knjižnice Marina Držića i Udruge Psi pomagači}

Odmah po osnivanju Udruge Psi pomagači 2014. godine, potaknuti primjerima dobre prakse iz zemalja razvijenijeg knjižničarstva ${ }^{30}$, knjižničari Dječje knjižnice Marina Držića iniciraju suradnju te predlažu uključivanje pasa pomagača u postojeći knjižnični program.

U to vrijeme udruga nosi naziv Psi pomagači - udruga za educiranje i certificiranje terapijskih timova i već tada, kao i danas, svoju misiju ostvaruje sljedećim djelatnostima: edukacijom terapijskih timova, uključivanjem educiranih timova u terapijske, odgojno-obrazovne i druge aktivnosti potpomognute psima te održavanjem stručnih predavanja i radionica. ${ }^{31}$ Udruga Psi pomaga$\check{c} i$ jedna je od svega nekoliko organizacija u Hrvatskoj koje se mogu pohvaliti članstvom u međunarodnoj udruzi Animal Assisted Intervention International te činjenicom da rade prema međunarodnim standardima. ${ }^{32}$ Držeći se tih standarda, stručnjaci iz Udruge Psi pomagači vode brigu o podjednakoj dobrobiti korisnika programa i pasa pomagača uključenih u rad, pa svojom profesionalnošću i etičnošću prednjače u programima intervencije potpomognute psima pomagačima u Hrvatskoj.

Početak suradnje obilježile su tri radionice u sklopu projekta Knjižnica širom otvorenih vrata koje su organizirane za dvogodišnjake s oštećenjima sluha iz DV Poliklinike SUVAG, predškolce s teškoćama u razvoju Udruge OZANA te učenike s teškoćama u razvoju OŠ Grigora Viteza. Cilj radionice pod nazivom I ja mogu, i ja znam bio je razvoj samopouzdanja, a sastojala se od zadataka koji su primarno zahtijevali fizičku aktivnost. Svladavajući improvizirani poligon djeca su pokazivala psu što mora napraviti, nagrađivala ga za dobro obavljen zadatak i pomagala mu kad ne bi uspio. Svijet osjetila bio je tema druge radionice, čiji je cilj bio istražiti i osvijestiti pet osnovnih osjetila. Sudjelujući u pet aktivnosti djeca su se zabavljala otkrivajući koji su okusi i mirisi ugodni njima, a koji psu, koje su razlike između njihova i psećeg sluha i vida te mogu li lako razlikovati dijelove psećeg tijela pomoću dodira. Dinamične i interaktivne radionice bile su posebno i novo iskustvo jer su djecu u svim aktivnostima i zadacima pratili psi pomagači Šira i Astra. Radionice su osmislile i vodile voditeljice pasa pomagača Tea Selaković i Vida Živković, imajući na umu da je okosnica rada sa psima pomagačima upravo činjenica da mogu kod djece podići razinu motivacije za različite aktivno-

\footnotetext{
30 Alameri, R. My mission is to listen: read to a dog - but not just any dog. // IFLA Helsinki 2012. [citirano: 2018-09-24]. Dostupno na: http://www.ifla.org/past-wlic/2012/160-alameri-en.pdf.

31 Pavlek, A. Pomažu, motiviraju, usrećuju: psi pomagači u Dječjoj knjižnici Marina Držića. // HKD Novosti 68(2016). Dostupno na: https://www.hkdrustvo.hr/hkdnovosti/clanak/1165 [citirano: 2018-09-24].

32 Animal Assisted Intervention International. Standard of practice. [citirano: 2018-09-24]. Dostupno na: https://aai-int.org/aai/standards-of-practice/.
} 
sti. Štoviše, jačina motivacije i emocije, koje se povećavaju u djetetu ugodnim i zanimljivim uvjetima rada, usko su povezane s učenjem.

Pozitivne reakcije sudionika prvih radionica motivirale su osnivače Udruge i knjižničare Dječje knjižnice da iste godine osmisle i zajedničku akciju za veći broj korisnika. Akcija Nađi svoj trag iziskivala je dodatna sredstva, a ona su dobivena zahvaljujući financijskoj podršci Zaklade ZAMAH. ${ }^{33}$ Dotadašnjim sudionicima radionica pridružuju se i djeca urednog razvoja te djeca s teškoćama u razvoju iz Dječjeg vrtića Vladimira Nazora.

Dječja knjižnica Marina Držića bila je nositelj navedene akcije koja je imala sljedeće ciljeve: uključiti pse pomagače u knjižnične aktivnosti, motivirati korisnike svih profila na dolaske u knjižnicu te promovirati knjižnicu kao tzv. treći prostor $^{34}$ lokalne zajednice. Uz teme već održanih radionica, osmišljene su i nove - Poštujmo tuđe različitosti, Kako se brinuti o psu, Znaš li kada je tvoj pas ljut, tužan, veseo? i Pričam ti priču - kojima se, osim poticanja općeg razvoja djece, nastojalo potaknuti i razvoj tolerancije, empatije, komunikacijskih, čitalačkih te drugih vještina. Tematske radionice te akcije bit će i okosnica novih ciklusa radionica tijekom narednih godina.

Tijekom 2015. godine u 6 radionica sudjelovalo je 78 djece različite dobi i razvojnog statusa, 28 pratitelja i 11 volontera. Anketni upitnik kojim je ispitano zadovoljstvo sudionika održanim radionicama, ispunilo je 51 dijete, kao i 23 pratitelja i 7 volontera. Svi ispitani pratitelji izrazili su želju da ponovno sudjeluju u radionicama, $96 \%$ ispitane djece izjavilo je da su im se radionice svidjele, a sami volonteri - studenti Edukacijsko-rehabilitacijskog fakulteta - radionice su ocijenili korisnima za buduće školovanje i rad. Pokazalo se da radionice iznimno pridonose inkluziji djece s teškoćama u razvoju jer potiču njihov opći razvoj te specifične sposobnosti na prilagođen i podržavajući način, a istodobno su poticajne i zanimljive djeci urednog razvoja.

Iako su u sklopu akcije psi pomagači sudjelovali u Pričaonicama te su tijekom radionica djeca čitala kraće tekstove i slobodno pregledavala knjižnični fond, manji broj pratitelja smatrao je da se radionicama poticao razvoj komunikacijskih i čitalačkih vještina. ${ }^{35}$ Rezultati evaluacije prve zajedničke akcije bitno su usmjerili daljnju suradnju i rad na unapređivanju radionica sa psima pomagačima.

Uspješno proveden projekt učvrstio je suradnički odnos između Dječje knjižnice i Udruge te se otada svake godine ostvarivalo partnerstvo u sklopu sličnih projekata čiju su vrijednost prepoznali i donatori poput Zaklade Adris, HEP-a i

33 Zaklada Zamah|Zaklada ZAMAH. [citirano: 2018-12-17]. Dostupno na: http://www.zamah. $\mathrm{hr} /$ zaklada-zamah/.

34 Ille, J. Dom, posao, nešto treće: knjižnica kao “treći prostor". // Narodne knjižnice kao treći prostor: zbornik radova / [urednice Dunja Marija Gabriel, Jelica Leščić]. Zagreb: Nacionalna i sveučilišna knjižnica, 2015. Str. 77-84.

35 Pavlek, A. Nav. dj. 
dm - drogerie markta Hrvatska. U razdoblju od 2015. do 2018. godine nositelj projekata bila je Udruga Psi pomagači

U sklopu projekta Tragači sreće u školskoj godini 2015./2016. održan je novi ciklus od 6 radionica, u sklopu projekata Tragači sreće i Naš put u školskoj godini 2016./2017. održano je 8 radionica, a projekt Naš put i volonterski angažman timova Udruge imali su za rezultat čak 14 radionica u školskoj godini 2017./2018. (vidi tablicu 1).

Tablica 1. Suradnja Udruge Psi pomagači i Dječje knjižnice Marina Držića

\begin{tabular}{|c|c|c|c|c|c|}
\hline \multicolumn{6}{|c|}{ 2014. godina } \\
\hline $\begin{array}{l}\text { Voditelj } \\
\text { radionice }\end{array}$ & & Tema radionice & Datum & Korisnici & $\begin{array}{c}\text { Broj } \\
\text { korisnika }\end{array}$ \\
\hline Tea Selaković & 1. & Svijet osjetila & 31. 10. & $\begin{array}{l}\text { Učenici s teškoćama u } \\
\text { razvoju 3. i 4. razreda OŠ } \\
\text { Grigora Viteza }\end{array}$ & 11 \\
\hline $\begin{array}{l}\text { Vida } \\
\text { Živković }\end{array}$ & 2. & $\begin{array}{l}\text { Jednostavne } \\
\text { aktivnosti i druženje } \\
\text { sa psom pomagačem }\end{array}$ & 21. 11. & $\begin{array}{l}\text { Predškolci Udruge } \\
\text { OZANA }\end{array}$ & 5 \\
\hline Tea Selaković & 3. & I ja mogu, i ja znam & 1. 12 . & $\begin{array}{l}\text { Skupina DV Poliklinike } \\
\text { SUVAG }\end{array}$ & 7 \\
\hline \multicolumn{5}{|c|}{ Ukupno posjeta: } & 23 \\
\hline \multicolumn{6}{|c|}{ 2015. godina } \\
\hline $\begin{array}{l}\text { Voditelj } \\
\text { radionice }\end{array}$ & & Tema radionice & Datum & Korisnici & $\begin{array}{c}\text { Broj } \\
\text { korisnika }\end{array}$ \\
\hline $\begin{array}{l}\text { Tea Selaković } \\
\text { i Vida } \\
\text { Živković }\end{array}$ & 1. & $\begin{array}{l}\text { Pričam ti priču - B. } \\
\text { Krajnović: Pas koji } \\
\text { je volio cvijeće }\end{array}$ & 9. 2 . & $\begin{array}{l}\text { Predškolci (od } 3 \text { do } 7 \\
\text { godina) }\end{array}$ & 19 \\
\hline Tea Selaković & 2. & I ja mogu, i ja znam & 20. 2. & $\begin{array}{l}\text { Skupina DV Poliklinike } \\
\text { SUVAG }\end{array}$ & 11 \\
\hline $\begin{array}{l}\text { Vida } \\
\text { Živković }\end{array}$ & 3. & $\begin{array}{l}\text { Pričam ti priču - B. } \\
\text { Krajnović: Pas koji } \\
\text { je volio cvijeće }\end{array}$ & 9. 3 . & $\begin{array}{l}\text { Skupina djece s } \\
\text { teškoćama DV Vladimira } \\
\text { Nazora }\end{array}$ & 11 \\
\hline Tea Selaković & 4. & Kako brinuti o psu & 23.3 . & $\begin{array}{l}\text { Učenici 3. razreda OŠ } \\
\text { Marina Držića }\end{array}$ & 11 \\
\hline $\begin{array}{l}\text { Vida } \\
\text { Živković }\end{array}$ & 5. & Kako brinuti o psu & 10. 4 . & $\begin{array}{l}\text { Učenici s teškoćama u } \\
\text { razvoju 3. i 4. razreda OŠ } \\
\text { Grigora Viteza }\end{array}$ & 9 \\
\hline
\end{tabular}




\begin{tabular}{|c|c|c|c|c|c|}
\hline Tea Selaković & 6. & Svijet osjetila & 24. 4. & $\begin{array}{l}\text { Učenici 4. razreda OŠ } \\
\text { Rapska }\end{array}$ & 17 \\
\hline $\begin{array}{l}\text { Sara } \\
\text { Mareković }\end{array}$ & 7. & I ja mogu, i ja znam & 22. 5. & Predškolci i školarci & 10 \\
\hline $\begin{array}{l}\text { Matea } \\
\text { Novosel }\end{array}$ & 8. & I ja mogu, i ja znam & 29. 5. & $\begin{array}{l}\text { Skupina DV Poliklinike } \\
\text { SUVAG }\end{array}$ & 6 \\
\hline $\begin{array}{l}\text { Sara } \\
\text { Mareković }\end{array}$ & 9. & $\begin{array}{l}\text { Pričam ti priču i } \\
\text { Kako brinuti o psu }\end{array}$ & 5. 10 & $\begin{array}{l}\text { Predškolci (od } 3 \text { do } 7 \\
\text { godina) }\end{array}$ & 27 \\
\hline $\begin{array}{l}\text { Sara } \\
\text { Mareković }\end{array}$ & 10. & $\begin{array}{l}\text { Znaš li kada je tvoj } \\
\text { pas tužan, ljut, } \\
\text { veseo? }\end{array}$ & 18. 12. & $\begin{array}{l}\text { Učenici OŠ Poliklinike } \\
\text { SUVAG }\end{array}$ & 16 \\
\hline \multicolumn{5}{|c|}{ Ukupno posjeta: } & 137 \\
\hline \multicolumn{6}{|c|}{ 2016. godina } \\
\hline $\begin{array}{l}\text { Voditelj } \\
\text { radionice }\end{array}$ & & Tema radionice & Datum & Korisnici & $\begin{array}{c}\text { Broj } \\
\text { korisnika }\end{array}$ \\
\hline $\begin{array}{l}\text { Sara } \\
\text { Mareković }\end{array}$ & 1. & Kako brinuti o psu & 22.1 & $\begin{array}{l}\text { Skupina DV Poliklinike } \\
\text { SUVAG }\end{array}$ & 11 \\
\hline $\begin{array}{l}\text { Vida } \\
\text { Živković }\end{array}$ & 2. & $\begin{array}{l}\text { Različite aktivnosti } \\
\text { i druženje sa psom } \\
\text { pomagačem }\end{array}$ & 3. 2 . & $\begin{array}{l}\text { Predškolci Udruge } \\
\text { OZANA }\end{array}$ & 6 \\
\hline $\begin{array}{l}\text { Matea } \\
\text { Novosel }\end{array}$ & 3. & $\begin{array}{l}\text { Poštujmo tuđe } \\
\text { različitosti }\end{array}$ & 15.2 & $\begin{array}{l}\text { Skupina DV Vladimira } \\
\text { Nazora }\end{array}$ & 10 \\
\hline Tea Selaković & 4. & $\begin{array}{l}\text { Jednostavne } \\
\text { aktivnosti i druženje } \\
\text { sa psom pomagačem }\end{array}$ & 22.2. & $\begin{array}{l}\text { Skupina djece s } \\
\text { teškoćama u razvoju DV } \\
\text { Vladimira Nazora }\end{array}$ & 3 \\
\hline $\begin{array}{l}\text { Sara } \\
\text { Mareković }\end{array}$ & 5. & $\begin{array}{l}\text { Znaš li kada je tvoj } \\
\text { pas tužan, ljut, } \\
\text { veseo? }\end{array}$ & 29. 2 . & $\begin{array}{l}\text { Učenici s teškoćama u } \\
\text { razvoju 3. razreda OŠ } \\
\text { Grigora Viteza }\end{array}$ & 5 \\
\hline $\begin{array}{l}\text { Sara } \\
\text { (Mareković) } \\
\text { Essert }\end{array}$ & 6. & $\begin{array}{l}\text { Čitanje priručnika o } \\
\text { gusarima } \\
\text { (Vau, kakva priča!) }\end{array}$ & 23. 9. & $\begin{array}{l}\text { Učenici 3. razreda OŠ } \\
\text { Poliklinike SUVAG }\end{array}$ & 13 \\
\hline $\begin{array}{l}\text { Vida } \\
\text { Živković }\end{array}$ & 7. & $\begin{array}{l}\text { S. Pilić: Maša i } \\
\text { životinje } \\
\text { (Vau, kakva priča!) }\end{array}$ & 21. 10. & $\begin{array}{l}\text { Učenici 2. razreda OŠ } \\
\text { Rapska }\end{array}$ & 19 \\
\hline $\begin{array}{l}\text { Yumiko } \\
\text { Yasue }\end{array}$ & 8. & Kako brinuti o psu & 24. 10 . & $\begin{array}{l}\text { Skupina DV Poliklinike } \\
\text { SUVAG }\end{array}$ & 10 \\
\hline
\end{tabular}




\begin{tabular}{|c|c|c|c|c|c|}
\hline $\begin{array}{l}\text { Vida } \\
\text { Živković }\end{array}$ & 9. & $\begin{array}{l}\text { Jednostavne } \\
\text { aktivnosti sa psom } \\
\text { pomagačem }\end{array}$ & 15. 12. & $\begin{array}{l}\text { Predškolci Udruge } \\
\text { OZANA }\end{array}$ & 7 \\
\hline \multicolumn{5}{|c|}{ Ukupno posjeta: } & 84 \\
\hline \multicolumn{6}{|c|}{ 2017. godina } \\
\hline $\begin{array}{l}\text { Voditelj } \\
\text { radionice }\end{array}$ & \multicolumn{2}{|r|}{ Tema radionice } & Datum & Korisnici & $\begin{array}{c}\text { Broj } \\
\text { korisnika }\end{array}$ \\
\hline Sara Essert & 1. & Kako brinuti o psu & 22.2. & $\begin{array}{l}\text { Učenici s teškoćama u } \\
\text { razvoju 4. razreda OŠ } \\
\text { Grigora Viteza }\end{array}$ & 5 \\
\hline Sara Essert & 2. & $\begin{array}{l}\text { Učimo slova sa psom } \\
\text { pomagačem } \\
(\text { Vau, kakva priča!) }\end{array}$ & 24. 3. & $\begin{array}{l}\text { Redovna skupina, } \\
\text { predškolski obveznici } \\
\text { DV Vladimira Nazora }\end{array}$ & 15 \\
\hline Sara Essert & 3. & $\begin{array}{l}\text { Jednostavne } \\
\text { aktivnosti sa psom } \\
\text { pomagačem }\end{array}$ & 3. 4 . & $\begin{array}{l}\text { Skupina djece s } \\
\text { teškoćama u razvoju } \\
\text { DV Vladimira Nazora }\end{array}$ & 1 \\
\hline $\begin{array}{l}\text { Yumiko } \\
\text { Yasue }\end{array}$ & 4. & I ja mogu, i ja znam & 8. 6. & $\begin{array}{l}\text { Učenici 1. razreda OŠ } \\
\text { Grigora Viteza }\end{array}$ & 12 \\
\hline Sara Essert & 5. & $\begin{array}{l}\text { Čitamo o biljkama } \\
\text { (Vau, kakva priča!) }\end{array}$ & 02.10 . & $\begin{array}{l}\text { Učenici 4. razreda OŠ } \\
\text { Poliklinike SUVAG }\end{array}$ & 15 \\
\hline $\begin{array}{l}\text { Yumiko } \\
\text { Yasue }\end{array}$ & 6. & $\begin{array}{l}\text { Čitamo lektiru - H. } \\
\text { C. Andersen: Ružno } \\
\text { pače } \\
\text { (Vau, kakva priča!) }\end{array}$ & 27. 10 . & $\begin{array}{l}\text { Učenici 2. razreda OŠ } \\
\text { Poliklinike SUVAG }\end{array}$ & 6 \\
\hline Sara Essert & 7. & $\begin{array}{l}\text { Čitamo lektiru - } \\
\text { E. Peroci: } \text { Maca } \\
\text { papučarica } \\
\text { (Vau, kakva priča!) }\end{array}$ & 30.10 . & $\begin{array}{l}\text { Učenici 2. razreda OŠ } \\
\text { Poliklinike SUVAG }\end{array}$ & 7 \\
\hline $\begin{array}{l}\text { Yumiko } \\
\text { Yasue }\end{array}$ & 8. & Kako brinuti o psu & 17. 11 . & $\begin{array}{l}\text { Skupina djece s } \\
\text { teškoćama Centra za } \\
\text { odgoj i obrazovanje } \\
\text { Goljak }\end{array}$ & 5 \\
\hline $\begin{array}{l}\text { Vida } \\
\text { Živković }\end{array}$ & 9. & Kako brinuti o psu & 4. 12 . & $\begin{array}{l}\text { Predškolci Udruge } \\
\text { OZANA }\end{array}$ & 6 \\
\hline Sara Essert & 10. & $\begin{array}{l}\text { Sudjelovanje u } \\
\text { interaktivnoj priči } \\
\text { Putovanje k Djedu } \\
\text { Božićnjaku } \\
\text { (Vau, kakva priča!) }\end{array}$ & 11. 12. & $\begin{array}{l}\text { Učenici 5. razreda OŠ } \\
\text { Grigora Viteza }\end{array}$ & 6 \\
\hline \multicolumn{5}{|c|}{ Ukupno posjeta: } & 78 \\
\hline
\end{tabular}




\begin{tabular}{|c|c|c|c|c|c|}
\hline \multicolumn{6}{|c|}{ 2018. godina } \\
\hline $\begin{array}{l}\text { Voditelj } \\
\text { radionice }\end{array}$ & & Tema radionice & Datum & Korisnici & $\begin{array}{c}\text { Broj } \\
\text { korisnika }\end{array}$ \\
\hline Tea Selaković & 1. & $\begin{array}{l}\text { Jednostavne } \\
\text { aktivnosti sa psom } \\
\text { pomagačem }\end{array}$ & 10.1 & $\begin{array}{l}\text { Školarci, korisnici Dječje } \\
\text { knjižnice }\end{array}$ & 3 \\
\hline $\begin{array}{l}\text { Yumiko } \\
\text { Yasue }\end{array}$ & 2. & $\begin{array}{l}\text { Čitanje priče C. } \\
\text { Pedler Zauvijek } \\
\text { zajedno + Kako } \\
\text { brinuti o psu } \\
\text { (Vau, kakva priča!) }\end{array}$ & 5. 2 . & $\begin{array}{l}\text { Predškolci (od } 3 \text { do } 7 \\
\text { godina) }\end{array}$ & 22 \\
\hline Tea Selaković & 3. & I ja mogu, i ja znam & 7. 2 . & $\begin{array}{l}\text { Školarci, korisnici Dječje } \\
\text { knjižnice (1 dijete s } \\
\text { teškoćama u razvoju) }\end{array}$ & 4 \\
\hline $\begin{array}{l}\text { Yumiko } \\
\text { Yasue }\end{array}$ & 4. & $\begin{array}{l}\text { Čitamo lektiru - N. } \\
\text { Videk: Pismo iz } \\
\text { Zelengrada }\end{array}$ & 20.2 . & $\begin{array}{l}\text { 2. razred OŠ Poliklinike } \\
\text { SUVAG }\end{array}$ & 6 \\
\hline Tea Selaković & 5. & $\begin{array}{l}\text { Poštujmo tuđe } \\
\text { različitosti }\end{array}$ & 7. 3. & $\begin{array}{l}\text { Školarci, korisnici Dječje } \\
\text { knjižnice (1 dijete s } \\
\text { teškoćama u razvoju) }\end{array}$ & 6 \\
\hline Sara Essert & 6. & $\begin{array}{l}\text { Učimo slova sa psom } \\
\text { pomagačem } \\
\text { (Vau, kakva priča!) }\end{array}$ & 14. 3 . & $\begin{array}{l}\text { Redovna skupina } \\
\text { i skupina djece s } \\
\text { teškoćama u razvoju } \\
\text { DV Vladimira Nazora }\end{array}$ & 10 \\
\hline $\begin{array}{l}\text { Ana-Marija } \\
\text { Šarić }\end{array}$ & 7. & $\begin{array}{l}\text { Jednostavne } \\
\text { aktivnosti sa psom } \\
\text { pomagačem }\end{array}$ & 4. 5. & $\begin{array}{l}\text { Školarci, korisnici Dječje } \\
\text { knjižnice }\end{array}$ & 6 \\
\hline $\begin{array}{l}\text { Yumiko } \\
\text { Yasue }\end{array}$ & 8. & Kako brinuti o psu & 18. 5. & $\begin{array}{l}\text { Skupina DV Vladimira } \\
\text { Nazora }\end{array}$ & 8 \\
\hline \multicolumn{5}{|c|}{ Ukupno posjeta: } & 65 \\
\hline
\end{tabular}

Budući da je poticanje čitanja jedan od primarnih zadataka svake narodne knjižnice, krajem 2016. godine Dječja knjižnica i Udruga zacrtale su cilj da se u sklopu radionica, osim na poticanju općeg razvoja djece i poticanju razvoja njihovih specifičnih sposobnosti, radi i na promicanju knjige i čitanja kad god je to moguće.

U sklopu 10 radionica u kojima je sudjelovalo 76 djece, slikovnice i knjige češće su korištene kao sredstvo za rad. Radionice je karakteriziralo čitanje kombinirano s dinamičnim aktivnostima i zadacima povezanima s tekstom i temom radionice. Radionice su većinom razradile voditeljice pasa pomagača Sara Essert 
i Yumiko Yasue, a u realizaciji radionica sudjelovali su njihovi psi pomagači Rio i Max. Za radionice su posebno bile zainteresirane učiteljice Osnovne škole Poliklinike SUVAG koje su pomagale pri njihovu planiranju sugerirajući teme, pomažući kod grafičke i jezične prilagodbe tekstova koji su se čitali, ali i asistirajući pri samoj realizaciji. Taj specifični ciklus radionica temelj je za budući program poticanja čitanja koji Dječja knjižnica i Udruga žele provoditi pod nazivom Vau, kakva priča!

\subsubsection{Suradnja Dječje knjižnice i Udruge Indeficienter}

Uspostavljanjem suradnje početkom 2016. godine s knjižničarom Željkom Radovićem, članom Udruge za pet therapy Indeficienter Vinkuran ${ }^{36}$, i uvođenjem programa R.E.A.D. bitno je nadopunjen knjižnični program čitanja u društvu pasa pomagača.

Udruga za pet therapy Indeficienter iz Vinkurana registrirana je 2012. godine kao prva udruga za provođenje terapija potpomognutih životinjama u Hrvatskoj. Udruga je 2014. godine postala podružnica za provođenje programa R.E.A.D. ${ }^{\circledR} \mathrm{u}$ Hrvatskoj te spomenuti program provodi volonterski pod nazivom Čitaj (o) psu. Program Čitaj (o) psu dobio je 2016. godine pozitivno stručno mišljenje Agencije za odgoj i obrazovanje te suglasnost Ministarstva znanosti i obrazovanja ${ }^{37}$.

Program R.E.A.D. (engl. Reading Education Assistance Dogs) pokrenula je 1999. godine američka organizacija Intermountain Therapy Animals iz Salt Lake Citya. Riječ je o prvom programu koji uključuje pse pomagače u odgojno-obrazovne i druge aktivnosti kako bi djeca unaprijedila čitalačke i komunikacijske vještine te prihvatila knjigu i čitanje. Okosnicu programa čini jednostavna metoda: čitanje psu. ${ }^{38}$

Program Čitaj (o) psu u Dječjoj knjižnici Marina Držića provodio se od ožujka 2016. do lipnja 2017. godine, a u njemu je redovito sudjelovala grupa učenika s disleksijom i teškoćama čitanja, formirana iz redovnih razrednih odjeljenja OŠ Grigora Viteza te pod nadzorom školskog knjižničara Marijana Malašića. Osim spomenute grupe, u programu su povremeno sudjelovali i učenici s teškoćama u razvoju iz iste škole te učenici s teškoćama čitanja i učenici urednog razvoja iz drugih škola. Čitaj (o) psu motivacijski je oblik programa kojemu je cilj učiniti djeci čitanje ugodnijim te ih potaknuti na daljnje čitanje. U navedenom razdoblju organizirano je 20 susreta u kojima je sudjelovalo 45 djece (vidi tablicu 2).

\footnotetext{
36 Usp. Udruga za pet therapy Indeficienter (UPTIV). [citirano: 2018-12-17]. Dostupno na: http://www.uptiv.hr/uptiv/.

37 Indeficienter. Čitaj (o) psu - R. E. A. D. 2016./2017. financijska potpora Ministarstva znanosti i obrazovanja. [citirano: 2018-09-24]. Dostupno na: http://www.uptiv.hr/item/citaj-opsu-r-e-a-d-2016-2017-financijska-potpora-minstarstva-znanosti-i-obrazovanja/.

38 Intermountain Therapy Animal - R.E.A.D. [citirano: 2018-09-24]. Dostupno na: http://www. therapyanimals.org/R.E.A.D.html.
} 
Tablica 2. Suradnja Udruge Indeficienter i Dječje knjižnice Marina Držića - program Citaj (o) psu

\begin{tabular}{|c|c|c|c|c|c|}
\hline \multicolumn{2}{|l|}{$\begin{array}{c}\text { Voditelj } \\
\text { radionica }\end{array}$} & Teme radionica & \multirow{2}{*}{$\frac{\text { Datum }}{\text { 7. } 3.2016 .}$} & \multirow{2}{*}{$\begin{array}{l}\text { Korisnici } \\
\text { Učenici 2. i 3. razreda OŠ } \\
\text { Marina Držića }\end{array}$} & \multirow{2}{*}{\begin{tabular}{|c}
$\begin{array}{c}\text { Broj } \\
\text { korisnika }\end{array}$ \\
6
\end{tabular}} \\
\hline \multirow{16}{*}{$\begin{array}{l}\text { Željko } \\
\text { Radović }\end{array}$} & 1. & $\begin{array}{l}\text { N. Mihelčić: Medalja } \\
\text { za hrabrost }\end{array}$ & & & \\
\hline & 2. & $\begin{array}{l}\text { J. i W. Grimm: } \\
\text { Mačak u čizmama }\end{array}$ & 14. 3. 2016 . & $\begin{array}{l}\text { Učenici 2. i 3. razreda OŠ } \\
\text { Marina Držića }\end{array}$ & 6 \\
\hline & 3. & $\begin{array}{l}\text { J. Donaldson: } \\
\text { Grubzon }\end{array}$ & 4. 4. 2016 . & $\begin{array}{l}\text { Učenici 2. i 3. razreda OŠ } \\
\text { Marina Držića }\end{array}$ & 6 \\
\hline & 4. & $\begin{array}{l}\text { N. Mihelčić: Medalja } \\
\text { za hrabrost }\end{array}$ & 25. 4. 2016 . & $\begin{array}{l}\text { Učenici 2. i 3. razreda OŠ } \\
\text { Grigora Viteza }\end{array}$ & 7 \\
\hline & 5. & \multirow{2}{*}{$\begin{array}{l}\text { S. Pilić: Maša i } \\
\text { životinje }\end{array}$} & 9. 5. 2016 . & $\begin{array}{l}\text { Učenici 2. i 3. razreda OŠ } \\
\text { Grigora Viteza }\end{array}$ & 6 \\
\hline & 6. & & 23. 5. 2016 . & $\begin{array}{l}\text { Učenici 2. i 3. razreda OŠ } \\
\text { Grigora Viteza }\end{array}$ & 6 \\
\hline & 7. & $\begin{array}{l}\text { P. Biet: Izgubio se } \\
\text { jedan zeleni pas }\end{array}$ & 6. 6. 2016 . & $\begin{array}{l}\text { Učenici 2. i 3. razreda OŠ } \\
\text { Grigora Viteza }\end{array}$ & 6 \\
\hline & 8. & \multirow{5}{*}{$\begin{array}{l}\text { P. O. Enquist: } \\
\text { Planina tri pećine }\end{array}$} & 26. 9. 2016. & $\begin{array}{l}\text { Učenici 3. i } 4 \text { razreda OŠ } \\
\text { Grigora Viteza }\end{array}$ & 7 \\
\hline & 9. & & 10. 10. 2016. & $\begin{array}{l}\text { Učenici 3. i } 4 \text { razreda OŠ } \\
\text { Grigora Viteza }\end{array}$ & 5 \\
\hline & 10. & & 5. 12. 2016 . & $\begin{array}{l}\text { Učenici 3. i } 4 \text { razreda OŠ } \\
\text { Grigora Viteza }\end{array}$ & 6 \\
\hline & 11. & & 19. 12. 2016 & $\begin{array}{l}\text { Učenici 3. i } 4 \text { razreda OŠ } \\
\text { Grigora Viteza }\end{array}$ & 6 \\
\hline & 12. & & 30. 1. 2017. & $\begin{array}{l}\text { Učenici 3. i } 4 \text { razreda OŠ } \\
\text { Grigora Viteza }\end{array}$ & 7 \\
\hline & 13. & $\begin{array}{l}\text { K. Čapek: Dašenjka } \\
\text { ili život šteneta }\end{array}$ & 13. 2. 2017. & $\begin{array}{l}\text { Učenici 3. i } 4 \text { razreda OŠ } \\
\text { Grigora Viteza }\end{array}$ & 7 \\
\hline & 14. & $\begin{array}{l}\text { Čitanje različitih } \\
\text { slikovnica o psima }\end{array}$ & 27. 2. 2017. & $\begin{array}{l}\text { Učenici s teškoćama u } \\
\text { razvoju 4. razreda OŠ } \\
\text { Grigora Viteza }\end{array}$ & 4 \\
\hline & 15. & $\begin{array}{l}\text { K. Čapek: Dašenjka } \\
\text { ili život šteneta }\end{array}$ & 13. 3. 2017. & $\begin{array}{l}\text { Učenici 3. i } 4 \text { razreda OŠ } \\
\text { Grigora Viteza }\end{array}$ & 7 \\
\hline & 16. & $\begin{array}{l}\text { Čitanje pjesama } \\
\text { najznačajnijih } \\
\text { hrvatskih pjesnika } \\
\text { za djecu }\end{array}$ & 21. 3. 2017. & $\begin{array}{l}\text { Učenici 1. razreda OŠ } \\
\text { Tina Ujevića }\end{array}$ & 20 \\
\hline
\end{tabular}




\begin{tabular}{|c|c|c|c|c|c|}
\hline $\begin{array}{l}\text { Voditelj } \\
\text { radionica }\end{array}$ & & Teme radionica & Datum & Korisnici & $\begin{array}{c}\text { Broj } \\
\text { korisnika }\end{array}$ \\
\hline \multirow{4}{*}{$\begin{array}{l}\text { Željko } \\
\text { Radović }\end{array}$} & 17. & $\begin{array}{l}\text { K. Čapek: Dašenjka } \\
\text { ili život šteneta }\end{array}$ & 5. 4. 2017. & $\begin{array}{l}\text { Učenici 3. i } 4 \text { razreda OŠ } \\
\text { Grigora Viteza }\end{array}$ & 7 \\
\hline & 18. & $\begin{array}{l}\text { Izlet u park } \\
\text { Maksimir }\end{array}$ & 10. 5. 2017. & $\begin{array}{l}\text { Učenici } 3 . \text { i 4. razreda } \\
\text { te učenici s teškoćama u } \\
\text { razvoju OŠ Grigora Viteza }\end{array}$ & 11 \\
\hline & 19. & $\begin{array}{l}\text { F. Lenk: Detektivske } \\
\text { zagonetke }\end{array}$ & 25. 5. 2017. & $\begin{array}{l}\text { Članovi čitateljskog kluba } \\
\text { Dječje knjižnice Marina } \\
\text { Držića }\end{array}$ & 7 \\
\hline & 20. & $\begin{array}{l}\text { S. Beraković: Hana i } \\
\text { Njuškalo }\end{array}$ & 8. 6. 2017. & $\begin{array}{l}\text { Učenici s teškoćama u } \\
\text { razvoju 4. razreda OŠ } \\
\text { Grigora Viteza }\end{array}$ & 4 \\
\hline \multicolumn{5}{|c|}{ Ukupno posjeta: } & 141 \\
\hline
\end{tabular}

Redovnu grupu činilo je 6 učenika koji su jednom do dva puta mjesečno dolazili na susret u Dječju knjižnicu te tijekom jednoga sata intenzivno čitali u društva psa pomagača Mare. Čitanje je povremeno prekidano pojašnjenjima i poticajima voditelja te zajedničkim razgovorom o tekstu koji se čitao.

U sklopu programa R.E.A.D. pročitane su slikovnice, zbirke pjesama i priča za djecu te dva kraća romana.

Anketnim upitnikom ispitano je zadovoljstvo članova redovne grupe održanim programom. Svim su se sudionicima radionice svidjele te su iskazali interes za daljnjim sudjelovanjem u programu. Četvero učenika redovne grupe (67 \% učenika redovne grupe) izjavilo je da se bolje osjeća kad čita u društvu psa pomagača. Pratitelj redovne grupe, školski knjižničar, bio je vrlo zadovoljan programom, smatrao je da su djeca unaprijedila vještinu čitanja te je iskazao interes za nastavkom suradnje.

\subsection{Knjižnica širom otvorenih vrata u Knjižnici Savica}

Knjižnica Savica u okviru programa Igraonica - pričaonica - maštaonica organizira pričaonice namijenjene poticanju čitanja i razumijevanja za učenike s teškoćama u razvoju nižih razreda osnovne škole koji se školuju po posebnom programu. U okviru programa Kreativne radionice i kulturna događanja u knjižnici se organiziraju susreti s književnicima, kreativne tematske radionice, geološke i ekološke radionice, psihološke i pedagoške radionice, izložbe radova te predstavljanja dječjih projekata. Radionice organiziraju knjižničari, a provode se u suradnji sa stručnjacima iz različitih područja, kao i u suradnji s organizacijama civilnog 
društva. Među tim programima ističe se ciklus psihološko-pedagoških radionica: $D a, m o g u !$ te ciklus pričaonica Možemo i mi! $!^{39}$

Spomenuti programi ostvaruju se u suradnji s OŠ Grigora Viteza koju, između ostalih, polazi i 125 učenika s teškoćama u razvoju. Ti učenici školuju se u manjim razrednim odjelima ovisno o vrsti i stupnju teškoće. Veći dio nastave za njih održavaju učitelji defektolozi, kao i jedan dio učitelja redovne predmetne nastave. Učenicima s teškoćama glasovno-govorne komunikacije i specifičnim teškoćama u razvoju stručnu podršku pružaju i dva školska logopeda. U školi se provode tri vrste tekućih programa: redovan, poseban program za djecu s organskim poremećajima u ponašanju, kao i poseban program namijenjen djeci usporena kognitivnog razvoja. ${ }^{40}$

\subsubsection{Ciklus radionica Da, mogu!}

Višegodišnja suradnja s učiteljicama posebnih odjeljenja OŠ Grigora Viteza pokazala je da, uza sve što se čini, postoji potreba za provođenjem još većeg broja kvalitetnih programa i radionica s vanjskim stručnjacima. Stoga je u školskoj godini 2016./2017. osmišljen ciklus psiholoških i pedagoških radionica $D a, m o g u$ ! koji se sastojao od šest radionica, posebno oblikovanih da se kroz njih pruži dodatna edukacijsko-rehabilitacijska podrška djeci i mladima s teškoćama u razvoju. Radionicama se također željelo povećati prepoznatljivost Knjižnica grada Zagreba u zajednici kao ustanove koja neprekidno radi na poboljšanju svojih usluga posvećenih najosjetljivijim društvenim skupinama.

Kada se djeci s teškoćama u razvoju pruži prilika da se ostvare kao i drugi, ona imaju potencijal voditi život koji ih ispunjava, kojim mogu pridonijeti socijalnoj, kulturnoj i gospodarskoj vitalnosti zajednica u kojima žive. Ipak, postizanje tog cilja djeci s teškoćama u razvoju može biti posebno zahtjevno i zbog toga je važno pružiti im svu moguću podršku da bi uspjela na tom putu. ${ }^{41}$ Ciklus radionica $D a$, mogu! bio je zamišljen kao niz psiholoških i srodnih radionica te radionica koje uključuju rad s tijelom. Tijekom 2016., 2017. i 2018. godine održano je ukupno deset radionica. Radionice su proveli edukacijski rehabilitatori i socijalni pedagozi.

Prvi ciklus radionica sastojao se od šest radionica i provodio se tijekom školske godine 2016./2017. Na njima su sudjelovali učenici šestog razreda s teškoćama u razvoju koji se školuju po posebnom programu.

39 Knjižnica Savica. Knjižnica širom otvorenih vrata. [citirano: 2018-09-09]. Dostupno na: http://www.kgz.hr/hr/knjiznice/knjiznica-savica/projekti-6204/knjiznica-sirom-otvorenih-vrata-6206/6206.

40 Osnovna škola Grigora Viteza Zagreb. Info o školi. [citirano: 2018-09-09]. Dostupno na: http://os-gviteza-zg.skole.hr/infor.

${ }^{41}$ UNICEF. Nav. dj., str. 3. 
Prva psihološka radionica zvala se Ispravan dodir, a bila je posvećena prepoznavanju i sprečavanju seksualnog zlostavljanja. Uslijedila je radionica Život je lijep uz igru i ples. Ta je radionica rada s tijelom uključivala vježbe fine motorike, vježbe lateralizacije (brain-gym-vježbe) i plesne vježbe.

Zatim je održana radionica Razvoj socijalnih vještina za bolje snalaženje $u$ svijetu koji nas okružuje. Ta psihološka iskustvena radionica bila je posvećena razvoju socijalnih vještina, dok je književna radionica Lektirni leptirići bila posvećena poticanju čitanja, razumijevanja i izražavanja. Psihoedukativna iskustvena radionica Rugaju mi se, što da radim? bila je posvećena razvoju socijalnih vještina, empatije i osvješćivanja postupaka koji su u osnovi pozitivnih poruka. Ciklus je zaokružen etnografsko-psihološkom radionicom Priča o Winnetouu na kojoj je bilo riječi o indijanskoj kulturi i važnosti prihvaćanja vlastite i tuđe različitosti (vidi tablicu 3). ${ }^{42}$

Tablica 3. Ciklus radionica Da, mogu! u Knjižnici Savica

\begin{tabular}{|l|l|l|l|c|}
\hline \multicolumn{1}{|c|}{$\begin{array}{c}\text { Naziv } \\
\text { radionice }\end{array}$} & \multicolumn{1}{|c|}{$\begin{array}{c}\text { Voditeljica } \\
\text { radionice }\end{array}$} & $\begin{array}{c}\text { Datum } \\
\text { održavanja }\end{array}$ & \multicolumn{1}{c|}{ Korisnici } & $\begin{array}{c}\text { Broj } \\
\text { korisnika }\end{array}$ \\
\hline Ispravan dodir & $\begin{array}{l}\text { Alemka Guštin, } \\
\text { socijalni pedagog, } \\
\text { defektolog i } \\
\text { socioterapeut }\end{array}$ & 22.11.2016. & $\begin{array}{l}\text { Učenici 6. razreda s } \\
\text { teškoćama u razvoju, } \\
\text { školovanje po } \\
\text { posebnom programu }\end{array}$ & 9 \\
\hline $\begin{array}{l}\text { Život je lijep uz } \\
\text { igru i ples }\end{array}$ & $\begin{array}{l}\text { Josipa Gorup- } \\
\text { Rožić, prof. } \\
\text { rehabilitator }\end{array}$ & 13.12.2016. & $\begin{array}{l}\text { Učenici 6. razreda s } \\
\text { teškoćama u razvoju, } \\
\text { školovanje po } \\
\text { posebnom programu }\end{array}$ & 8 \\
\hline $\begin{array}{l}\text { Razvoj socijalnih } \\
\text { vještina za bolje } \\
\text { snalaženje u } \\
\text { svijetu koji nas } \\
\text { okružuje }\end{array}$ & $\begin{array}{l}\text { Maja Kević, prof. } \\
\text { rehabilitator }\end{array}$ & 23.2.2017. & $\begin{array}{l}\text { Učenici 6. razreda s } \\
\text { teškoćama u razvoju, } \\
\text { školovanje po } \\
\text { posebnom programu }\end{array}$ & 6 \\
\hline Lektirni leptirići & $\begin{array}{l}\text { Dubravka Žderić, } \\
\text { prof. rehabilitator }\end{array}$ & 3.4 .2017$. & $\begin{array}{l}\text { Učenici 6. razreda s } \\
\text { teškoćama u razvoju, } \\
\text { školovanje po } \\
\text { posebnom programu }\end{array}$ & 7 \\
\hline $\begin{array}{l}\text { Rugaju mi se, što } \\
\text { da radim? }\end{array}$ & $\begin{array}{l}\text { Jelena Šuk, } \\
\text { socijalni pedagog }\end{array}$ & 27.4.2017. & $\begin{array}{l}\text { Učenici 6. razreda s } \\
\text { teškoćama u razvoju, } \\
\text { školovanje po } \\
\text { posebnom programu }\end{array}$ & 8 \\
\hline
\end{tabular}

${ }^{42}$ Usp. Izvještaji Knjižnice Marina Držića za razdoblje 2016. - 2017. godine. Arhiva Knjižnice Marina Držića. [interni dokumenti] 


\begin{tabular}{|c|c|c|c|c|}
\hline $\begin{array}{c}\text { Naziv } \\
\text { radionice }\end{array}$ & $\begin{array}{l}\text { Voditeljica } \\
\text { radionice }\end{array}$ & $\begin{array}{c}\text { Datum } \\
\text { održavanja }\end{array}$ & Korisnici & $\begin{array}{c}\text { Broj } \\
\text { korisnika }\end{array}$ \\
\hline $\begin{array}{l}\text { Priča o } \\
\text { Winnetouu }\end{array}$ & $\begin{array}{l}\text { Dubravka Žderić, } \\
\text { prof. rehabilitator }\end{array}$ & 29. 5. 2017. & $\begin{array}{l}\text { Učenici 6. razreda s } \\
\text { teškoćama u razvoju, } \\
\text { školovanje po } \\
\text { posebnom programu }\end{array}$ & 9 \\
\hline $\begin{array}{l}\text { Kako } \\
\text { komunicirati } \\
\text { na društveno } \\
\text { prihvatljiv način }\end{array}$ & $\begin{array}{l}\text { Maja Kević, prof. } \\
\text { rehabilitator }\end{array}$ & 29. 11. 2017. & $\begin{array}{l}\text { Učenici 7. razreda s } \\
\text { teškoćama u razvoju, } \\
\text { školovanje po } \\
\text { posebnom programu }\end{array}$ & 9 \\
\hline $\begin{array}{l}\text { Samopouzdanje } \\
\& \\
\text { samopoštovanje }\end{array}$ & $\begin{array}{l}\text { Alemka Guštin, } \\
\text { defektolog, } \\
\text { socijalni pedagog i } \\
\text { socioterapeut }\end{array}$ & 17. 11. 2017. & $\begin{array}{l}\text { Učenici 7. razreda s } \\
\text { teškoćama u razvoju, } \\
\text { školovanje po } \\
\text { posebnom programu }\end{array}$ & 9 \\
\hline $\begin{array}{l}\text { Jezične } \\
\text { zavrzlame }\end{array}$ & $\begin{array}{l}\text { Dubravka Žderić, } \\
\text { prof. rehabilitator }\end{array}$ & 16. 5. 2018 . & $\begin{array}{l}\text { Učenici 7. razreda s } \\
\text { teškoćama u razvoju, } \\
\text { školovanje po } \\
\text { posebnom programu }\end{array}$ & 8 \\
\hline $\begin{array}{l}\text { Kako se } \\
\text { odgovorno } \\
\text { ponašati u prirodi }\end{array}$ & $\begin{array}{l}\text { Vedrana Vitez, } \\
\text { prof. rehabilitator i } \\
\text { socioterapeut }\end{array}$ & 11. 10. 2018. & $\begin{array}{l}\text { Učenici 8. razreda s } \\
\text { teškoćama u razvoju, } \\
\text { školovanje po } \\
\text { posebnom programu }\end{array}$ & 8 \\
\hline Ukupno posjeta: & & & & 81 \\
\hline
\end{tabular}

Učiteljica koja je na te radionice dovodila svoje učenike na kraju ciklusa napisala je sljedeću evaluaciju koja je objavljena na mrežnoj stranici OŠ Grigora Viteza: ${ }^{43}$

Tijekom šk. godine 2016./17. učenici 6e razreda (djeca s teškoćama u razvoju, školovanje po posebnom programu) OŠ Grigora Viteza prisustvovali su na 6 radionica u Knjižnici Savica. Radionice su vodile stručne osobe pedagoške struke, a uključivale su psihološka, senzomotorička, književna, etnografska i edukativna područja. Sve radionice bile su korisne učenicima, od upoznavanja nepoznatih osoba, razvoja komunikacije, bogaćenja rječnika, razvoja kulturnog ophođenja, adekvatnog funkcioniranja, izvođenja svakodnevnih zadataka i komunikacije s vanjskim svijetom, snalažljivosti, kreativnosti... Svaka je radionica bila kombinacija intelektualnog i kreativnog pristupa, djeca su učila na zanimljiv i interaktivan način, pokazivali su želju i interes za stjecanje novih znanja, razvijali su komunikacijske sposobnosti i sposobnosti neovisnog promišljanja.

43 Osnovna škola Grigora Viteza Zagreb. Vijesti - Radionice u Gradskoj knjižnici „Savica“. [citirano: 2018-09-09]. Dostupno na: http://www.os-gviteza-zg.skole.hr/vijesti?news hk $=5406 \&$ news_id=972\&mshow $=878$. 
Svaka radionica djeci je ostala u lijepom sjećanju, no najviše ih se dojmila psihološka radionica posvećena razvoju socijalnih vještina. Učenici su naučili poštovati osobnost svakog djeteta i njegovih želja, prihvatili su individualne potrebe svakog pojedinca, osvijestili usvajanje osjetilnih informacija iz okoline i vlastitog tijela. Stekli su sigurnost u sebe i ponosni su jer su i sami tome pridonijeli i učinili radionicu zanimljivom i edukativnom. Učenici su se veselili svakoj novoj radionici, prepričavali roditeljima i ostalim profesorima svoja iskustva, njihova radost i zadovoljstvo odlaskom u knjižnicu bila je prisutna svaki put. Ipak je to bilo usvajanje novih znanja i sposobnosti na jednostavniji način uz puno manje muke i školskog stresa!

Izjave i dojmovi nekoliko učenika o radionicama:

E. H: Puno sam toga čula i vidjela što nikad ne bih sama kod kuće.

P. K: Jako volim crtati i bojati, stalno radimo neke zanimljive stvari.

E. M: Sve me to zabavljalo. Puno toga sam i prije znao ali sam puno toga i u knjižnici saznao. Mislim da ništa ne treba dodati ni oduzeti radionicama i čekam 7. razred za nove.

Zahvaljujući pozitivnim povratnim informacijama te stečenim iskustvima, u dogovoru s učiteljicom i stručnim suradnicima osmišljeno je još nekoliko radionica. Tako su ujesen 2017. godine održane još dvije radionice: psihoedukativna iskustvena radionica Kako komunicirati na društveno prihvatljiv način i psihološka radionica Samopouzdanje \& samopoštovanje. I u 2018. godini održane su dvije radionice: jedna je bila posvećena poticanju čitanja, razumijevanja i izražavanja i zvala se Jezične zavrzlame, a druga osnovama planinarenja i snalaženja u prirodi nazvana Kako se odgovorno ponašati u prirodi. ${ }^{44}$

\subsubsection{Ciklus pričaonica Možemo i mi!}

Dobar prijam radionica održanih u okviru ciklusa $D a, m o g u$ ! potaknuo je osmišljavanje sličnog ciklusa za učenike nižih razreda osnovne škole koji se također školuju po posebnom programu. Taj se ciklus provodi u okviru programa Igraoni$c a$ - pričaonica-maštaonica, a sastoji se od nekoliko pričaonica i lutkarske predstave. Pričaonice su posvećene određenim temama kao što su razvijanje socijalnih i praktičnih vještina, osnaživanje samopouzdanja, poticanje razvoja grafomotorike te predvještina i vještina čitanja i pisanja i sl., a ciklus zaokružuje lutkarska pred-

\footnotetext{
44 I sami učenici nakon svake radionice ispunjavali su anketni upitnik kojim se ispitivalo zadovoljstvo sudionika provedenim radionicama. Na radionicama je sudjelovalo između 6 i 9 učenika. Anketni je upitnik ispunilo 78 sudionika, od kojih je $98 \%$ izjavilo da su im se radionice svidjele i da žele doći na nove.
} 
stava u izvedbi članova i volontera Centra Pričaj $m i^{45} \mathrm{~s}$ kojima knjižnica njeguje višegodišnju suradnju (vidi tablicu 4). ${ }^{46}$ Prvi takav ciklus osmišljen je i proveden u školskoj godini 2017./2018., a slijedi osvrt učiteljica s kojima se surađivalo u njegovoj provedbi:

Odlasci na radionice u knjižnicu s našim učenicima s teškoćama u razvoju predstavljali su za njih (ali i za nas) prave događaje tijekom školske godine. Učenici (uzrasta 2. - 4. r. koji se školuju po Posebnom nastavnom planu i programu) su s veseljem prihvatili pričanje priča/slikovnica koje je voditeljica radionica vrlo profesionalno i kreativno pripremila, ali i prilagodila našim učenicima i njihovim sposobnostima. Sa zanimanjem su pratili, sudjelovali, razgovarali i izrađivali ponuđeni materijal. Zanimljivo je i s koliko su pažnje popratili rad, ako uzmemo u obzir da je upravo distraktibilna pažnja jedna od njihovih teškoća. U školi su se često prisjećali i prepričavali dogodovštine iz knjižnice ili spominjali likove iz priča. Također, učenici su imali priliku doživjeti knjižnicu ne samo kao mjesto posudbe i vraćanja literature, već i kao ugodno mjesto učenja, zabave i suradnje, a zanimanje knjižničara doživjeti ne samo kao namještenika knjižnice, već i aktivnog edukatora.

Knjižničarka nas je svojim načinom rada i pristupom djeci potaknula da i same uvedemo više ovakvog oblika rada u svakodnevnu školsku sredinu. Zaista, svaka pohvala za ideju i provedbu ovih kvalitetnih radionica od kojih djeca imaju koristi u poticanju interesa za čitanjem priča i slikovnica, a kroz koji se višestruko utječe na njihov razvoj i napredak. Želja nam je nastaviti s pohađanjem radionica i njegovati ovako dobru i kvalitetnu suradnju s knjižnicom. ${ }^{47}$

Tablica 4. Ciklus pričaonica Možemo i mi! u Knjižnici Savica

\begin{tabular}{|l|l|l|l|c|}
\hline $\begin{array}{c}\text { Naziv pričaonice } \\
\text { ili predstave }\end{array}$ & $\begin{array}{l}\text { Voditeljica pričaonice ili } \\
\text { izvoditelji predstave }\end{array}$ & $\begin{array}{c}\text { Datum } \\
\text { održavanja }\end{array}$ & \multicolumn{1}{c|}{ Korisnici } & $\begin{array}{c}\text { Broj } \\
\text { korisnika }\end{array}$ \\
\hline Priča o Hrkalu & $\begin{array}{l}\text { Snježana Ercegovac, dipl. } \\
\text { knjižničarka }\end{array}$ & 21.3.2018. & $\begin{array}{l}\text { Učenici 2., 3. i } \\
\text { 4. razreda }\end{array}$ & 5 \\
\hline $\begin{array}{l}\text { Priča o Kristoforu } \\
\text { Grickiću i } \\
\text { gusjenicama }\end{array}$ & $\begin{array}{l}\text { Snježana Ercegovac, dipl. } \\
\text { knjižničarka }\end{array}$ & 12.4. 2018. & $\begin{array}{l}\text { Učenici 2., 3. i } \\
\text { 4. razreda }\end{array}$ & 10 \\
\hline
\end{tabular}

45 Više informacijama o aktivnostima Centra Pričaj mi dostupno je na mrežnoj stranici http:// pricajmi.hr/.

${ }^{46}$ Na predstavu bivaju pozvani i svi ostali učenici s teškoćama u učenju koji se školuju po posebnom programu, s čijim učiteljicama knjižnica surađuje.

47 Usp. Izvještaji Knjižnice Marina Držića za razdoblje 2017. - 2018. godine. Arhiva Knjižnice Marina Držića. [interni dokumenti] 


\begin{tabular}{|l|l|l|l|c|}
\hline $\begin{array}{c}\text { Naziv pričaonice } \\
\text { ili predstave }\end{array}$ & $\begin{array}{l}\text { Voditeljica pričaonice ili } \\
\text { izvoditelji predstave }\end{array}$ & $\begin{array}{c}\text { Datum } \\
\text { održavanja }\end{array}$ & \multicolumn{1}{c|}{ Korisnici } & $\begin{array}{c}\text { Broj } \\
\text { korisnika }\end{array}$ \\
\hline $\begin{array}{l}\text { Ne baš savršen } \\
\text { pingvin }\end{array}$ & $\begin{array}{l}\text { Snježana Ercegovac, dipl. } \\
\text { knjižničarka }\end{array}$ & 9.5.2018. & $\begin{array}{l}\text { Učenici 2., 3. i } \\
\text { 4. razreda }\end{array}$ & 7 \\
\hline $\begin{array}{l}\text { Predstava } \\
\text { „Najotmjeniji div u } \\
\text { gradu“ }\end{array}$ & Centar Pričaj mi & 7.6.2018. & $\begin{array}{l}\text { Učenici 2., 3., 4. } \\
\text { i 7. razreda }\end{array}$ & 18 \\
\hline Ukupno posjeta: & & & & $\mathbf{4 0}$ \\
\hline
\end{tabular}

S obzirom na pozitivne osvrte ${ }^{48}$, osmišljen je novi ciklus pričaonica za školsku godinu 2018./2019. i u planu je njegova daljnja provedba.

\section{Programi za osobe s teškoćama čitanja i disleksijom}

\subsection{Maštom do čitanja - projekt Hrvatske udruge za disleksiju}

U Dječjoj knjižnici Marina Držića i Knjižnici Savica prve radionice posvećene teškoćama čitanja i disleksiji održane su 2010. godine. Tada je u suradnji s Hrvatskom udrugom za disleksiju proveden projekt Maštom do čitanja. ${ }^{49}$ Radionice su se održavale u sklopu Pričaonice, redovitog programa u objema knjižnicama. Tijekom studenog i prosinca 2010. godine održano je sedam radionica na kojima je sudjelovalo 114 djece u dobi od 3 do 7 godina.

Radionice u sklopu tog projekta bile su usmjerene na razvoj vještina koje čine temelj uspješnog čitanja i pisanja - kao što su prepoznavanje glasova i njihovo razlikovanje, povezivanje glasova i slova, slušno pamćenje, vizualna percepcija i grafomotorika - i zbog toga su obuhvaćale igre u prostoru namijenjene razvoju prostorne orijentacije, igre prepoznavanja i osvještavanja govornih zvukova te igre prepoznavanja rime i ritma. Starija su djeca sudjelovala u igrama prepoznavanja govornih zvukova, analize i sinteze. Još jedan cilj projekta bio je motivirati djecu da otkriju svijet knjiga, priča i bajki kao prvi korak u svijet pismenosti, stoga je temelj svake radionice činila odabrana priča ili bajka.

48 Učenici koji su dolazili na taj ciklus također su ispunjavali anketni upitnik za ispitivanje zadovoljstva sudionika provedenim pričaonicama. Tu skupinu činili su učenici triju razreda. Na svakoj pričaonici bilo je između 5 i 10 učenika. U prvom su ciklusu održane 3 pričaonice i jedna predstava. Anketni je upitnik ispunilo 38 sudionika, od kojih je $98 \%$ izjavilo da su im se pričaonice i predstava svidjele i da žele doći na nove.

49 Usp. Hrvatska udruga za disleksiju. Knjižnice i disleksija 2002. - 2010. [citirano: 2018-0909]. Dostupno na: http://hud.hr/knjiznice-i-disleksija/. 
Budući da predčitalačke vještine djeca usvajaju igrajući se, listajući slikovnice, pjevajući pjesmice te sudjelujući u igrama riječima s roditeljima i vršnjacima, provedenim se radionicama kod predškolaca pokušalo pokrenuti razvoj tih vještina, kao i pomoći roditeljima da osvijeste koliko je njihov razvoj važan za uspješno školovanje. Taj je projekt bio nagrađen kao najbolji međunarodni projekt na natječaju Phillip Lese Award u organizaciji bečkog Jugend Buch kluba i OMV-a. ${ }^{50}$

Pričaonice i radionice za poticanje čitanja i razvoj mašte u kontinuitetu su se nastavile održavati i nakon tog projekta, a početkom 2018. godine, uključivanjem u provedbu kampanje I ja želim čitati! i suradnjom s Logopedskim centrom Govorni Oblačićs ${ }^{51}$, u objema su se knjižnicama ponovno počele održavati logopedske radionice za djecu ili za djecu i roditelje, a u Knjižnici Savica i logopedska predavanja za roditelje i sve zainteresirane.

\subsection{Nacionalna kampanja I ja želim čitati!}

Nacionalnu kampanju I ja želim čitati! pokrenuli su Hrvatsko knjižničarsko društvo, Knjižnice grada Zagreba i Nacionalna i sveučilišna knjižnica. Cilj je kampanje informirati i educirati javnost te ju učiniti osjetljivom za problematiku osoba s teškoćama čitanja i disleksijom. Usto, kampanjom se želi poboljšati međuinstitucionalna suradnja stručnjaka koji se bave osobama s teškoćama čitanja i disleksijom te osobama koje ne mogu čitati standardni tisak. ${ }^{52}$

Provedba kampanje potiče se raznovrsnim akcijama: organiziranjem izložaba na temu osoba s teškoćama u čitanju, provođenjem radionica i održavanjem predavanja za roditelje i nastavnike te rješavanjem konkretnih svakodnevnih problema s kojima se određena ciljna skupina susreće.

Dječja knjižnica Marina Držića uključila se u nacionalnu kampanju I ja želim čitati! osnivanjem kutka za zbirku koja sadrži literaturu o teškoćama čitanja, zvučne knjige i građu laganu za čitanje. Zbirka je utemeljena na građi izlučenoj iz postojećeg fonda knjižnice.

Preporučeni popis knjiga za roditelje Kad slova plešu, objavljen u Mjesecu hrvatske knjige 2017., sadrži popis knjiga u kojima autori pišu o teškoćama čitanja. ${ }^{53}$

\footnotetext{
50 Isto.

51 Usp. Logopedski centar Govorni Oblačić. [citirano: 2018-12-22]. Dostupno na: https://logopedski-centar.com/.

52 Usp. I ja želim čitati. Nav. dj.

53 Knjižnice grada Zagreba. Dječja knjižnica Marina Držića. [citirano: 2018-09-09]. Dostupno na: http://www.kgz.hr/hr/knjiznice/djecja-knjiznica-marina-drzica/59.
} 
Kao prilog kampanji, a u suradnji s Logopedskim centrom Govorni Oblačićc ${ }^{4}$, organizirane su tri radionice za djecu i roditelje o utjecaju aktivnog čitanja i pripovijedanja na jezični razvoj djeteta, kao i o aktivnostima za poticanje predvještina čitanja, pisanja i računanja. Radionice su održale logopedinje Martina Labaš Batković i Ruža Petric. Jedna radionica održana je za djecu i roditelje u sklopu Pričaonice, redovne aktivnosti Dječje knjižnice, druga za djecu i roditelje iz Dječjeg vrtića Dobro Drvo te treća za djecu i odgojiteljice iz Dječjeg vrtića Iskrica. Od početka godine knjižnica s Dječjim vrtićem Dobro Drvo organizira redovite grupne posjete uz pričanje priča i likovne radionice. Djeca iz Dječjeg vrtića Iskrica sudjeluju u spomenutim logopedskim radionicama jer vrtić nema logopeda. Na tim je radionicama sudjelovalo 53 djece i 25 odraslih. ${ }^{55}$

U Knjižnici Savica, zahvaljujući suradnji s logopedinjama iz spomenutog logopedskog centra, održana su tri predavanja posvećena temama kao što su govorni poremećaji, razvoj govora i komunikacije te disleksija u odrasloj dobi. Predavanja su bila namijenjena roditeljima, ali i stručnjacima i svima zainteresiranima. Osim tih predavanja, održane su i dvije radionice za djecu predškolske obveznike. ${ }^{56}$

Interaktivno predavanje Kada k logopedu? obuhvatilo je kratki pregled komunikacijskog i jezično-govornog razvoja, odstupanja u komunikacijskom i jezično-govornom razvoju te čitanju i pisanju, a govorilo se i o tome što učiniti nakon prepoznavanja teškoća. Drugo predavanje, Komunikacija, jezik, govor-piramida razvoja, bilo je posvećeno ranom komunikacijskom razvoju koji započinje rođenjem djeteta, razlozima zbog kojih je rana komunikacija važna, kako primijetiti odstupanja u ranom razvoju te koji su načini poticanja komunikacijskog, a posljedično i jezično-govornog razvoja. Treće predavanje, Disleksija kod odraslih, bilo je posvećeno predstavljanju temeljnih obilježja disleksije u odraslih, objašnjavanju funkcioniranja odraslih s disleksijom te načinima prilagodbe i podrške za studente s disleksijom u okviru akademskog obrazovanja uz mogućnosti daljnjeg zapošljavanja.

Na radionici Ususret školi sudjelovale su dvije vrtićke skupine predškolaca iz Dječjeg vrtića Savica, a radionica je bila posvećena poticanju razvoja predvještina čitanja, pisanja i računanja, razvoju koncentracije i ustrajnosti, kao i razvoju vještina jezičnog izražavanja i pripovijedanja. Na tim je programima sudjelovalo 45 odraslih i 48 djece (vidi tablicu 5). ${ }^{57}$

\footnotetext{
54 Logopedski Centar Govorni Oblačić osnovan je početkom 2018. godine s ciljem pružanja stručne logopedske podrške u vidu prevencije, rane intervencije, identifikacije i tretiranja teškoća komunikacijskog i jezično-govornog razvoja djece od najranije dobi.

55 Izvještaj Knjižnice Marina Držića za 2018. godinu. Arhiva Knjižnice Marina Držića. [interni dokument]

56 Isto.

57 Isto.
} 
Tablica 5. Suradnja s Logopedskim centrom Govorni Oblačić

\begin{tabular}{|c|c|c|c|c|c|}
\hline \multicolumn{6}{|c|}{ Dječja knjižnica Marina Držića } \\
\hline $\begin{array}{l}\text { Predavačice } \\
\text { / voditeljice } \\
\text { radionica }\end{array}$ & \multicolumn{2}{|c|}{$\begin{array}{l}\text { Naziv predavanja ili } \\
\text { radionice }\end{array}$} & Datum & Korisnici & $\begin{array}{l}\text { Ukupan broj } \\
\text { korisnika }\end{array}$ \\
\hline \multirow{3}{*}{$\begin{array}{l}\text { Martina Labaš } \\
\text { Batković i } \\
\text { Ruža Petric }\end{array}$} & 1. & $\begin{array}{l}\text { Utjecaj aktivnog } \\
\text { čitanja i } \\
\text { pripovijedanja } \\
\text { na jezični razvoj } \\
\text { djeteta }\end{array}$ & 05. 3. 2018 & $\begin{array}{l}\text { Predškolci i } \\
\text { njihovi roditelji }\end{array}$ & $\begin{array}{l}40 \text { (od toga } \\
15 \text { odraslih } \\
\text { korisnika) }\end{array}$ \\
\hline & 2. & $\begin{array}{l}\text { Poticanje razvoja } \\
\text { predvještina čitanja } \\
\text { i pisanja }\end{array}$ & 08. 5. 2018. & $\begin{array}{l}\text { Predškolci i } \\
\text { njihovi roditelji }\end{array}$ & $\begin{array}{l}15 \text { (od toga } \\
7 \text { odraslih } \\
\text { korisnika) }\end{array}$ \\
\hline & 3. & $\begin{array}{l}\text { Poticanje razvoja } \\
\text { predvještina čitanja } \\
\text { i pisanja }\end{array}$ & 28. 5. 2018. & $\begin{array}{l}\text { Vrtićka skupina } \\
\text { predškolskih } \\
\text { obveznika i } \\
\text { odgojiteljice }\end{array}$ & 20 \\
\hline \multicolumn{5}{|l|}{ Ukupno posjeta: } & 75 \\
\hline \multicolumn{6}{|c|}{ Knjižnica Savica } \\
\hline $\begin{array}{l}\text { Predavačice } \\
\text { / voditeljice } \\
\text { radionica }\end{array}$ & \multicolumn{2}{|c|}{$\begin{array}{l}\text { Naziv predavanja ili } \\
\text { radionice }\end{array}$} & Datum & Korisnici & $\begin{array}{l}\text { Ukupan broj } \\
\text { korisnika }\end{array}$ \\
\hline \multirow{4}{*}{\begin{tabular}{l|} 
Martina Labaš \\
Batković i \\
Ruža Petric
\end{tabular}} & 1. & Kada k logopedu? & 20. 12. 2018. & \multirow{3}{*}{$\begin{array}{l}\text { Odrasli } \\
\text { korisnici }\end{array}$} & \multirow{3}{*}{45} \\
\hline & 2. & $\begin{array}{l}\text { Komunikacija, } \\
\text { jezik, govor - } \\
\text { piramida razvoja }\end{array}$ & 26. 3. 2018 . & & \\
\hline & 3. & $\begin{array}{l}\text { Disleksija u odrasloj } \\
\text { dobi }\end{array}$ & 30. 10. 2018 . & & \\
\hline & 4. & Ususret školi & $\begin{array}{l}\text { 14. i } 17.5 . \\
2018 .\end{array}$ & $\begin{array}{l}\text { Vrtićke skupine } \\
\text { predškolskih } \\
\text { obveznika }\end{array}$ & 48 \\
\hline \multicolumn{5}{|l|}{ Ukupno posjeta: } & 93 \\
\hline
\end{tabular}

\section{Zaključak}

Dječja knjižnica Marina Držića i Knjižnica Savica, ogranci Knjižnice Marina Držića, knjižnice u mreži Knjižnica grada Zagreba, nalaze se u gradskoj četvrti Trnje u kojoj je i znatan broj ustanova i organizacija koje skrbe za djecu s teškoćama u razvoju i mlade s invaliditetom. U neposrednom okruženju knjižnica djeluju 
Poliklinika za rehabilitaciju slušanja i govora SUVAG, Udruga OZANA, Dječji vrtić Vladimira Nazora i Osnovna škola Grigora Viteza.

Izlazeći u susret potrebama korisnika u svojoj lokalnoj zajednici, knjižnice već dugi niz godina ostvaruju suradnju sa spomenutim ustanovama i organizacijama. I prije 2007. godine, kada se uključuju u projekt Knjižnica širom otvorenih vrata, Dječja knjižnica Marina Držića i Knjižnica Savica u svoje redovite aktivnosti i programe uključuju djecu s teškoćama u razvoju i mlade s invaliditetom. U novije doba, uključivanjem u nacionalnu kampanju I ja želim čitati!, posebna se pozornost posvećuje djeci s teškoćama čitanja i disleksijom.

Posljednjih godina knjižnice na osmišljavanju i realizaciji programa rade surađujući s brojnim stručnjacima i organizacijama civilnog društva. Obogaćen i unaprijeđen program u koji se uključuju djeca s teškoćama u razvoju knjižnice nastoje provoditi sustavno i kontinuirano. Takav pristup, prije svega, rezultira pozitivnim pomacima u općem razvoju djece s teškoćama u razvoju koja sudjeluju u programu. Zatim, na taj se način jačaju i poboljšavaju suradnički odnosi između knjižnica i ustanova koje provode odgojno-obrazovni program za djecu s teškoćama i mlade s invaliditetom. I na kraju, ponuda atraktivnih, inovativnih i djeci s teškoćama prilagođenih programa knjižnice čini prepoznatljivima ne samo unutar lokalne zajednice nego i šire.

\section{LITERATURA}

Alameri, R. My mission is to listen: read to a dog - but not just any dog. // IFLA Helsinki 2012. [citirano: 2018-09-24]. Dostupno na: http://www.ifla.org/past-wlic/2012/160-alameri-en.pdf.

Animal Assisted Intervention International - Standard of Practice. [citirano: 2018-0924]. Dostupno na: https://aai-int.org/aai/standards-of-practice/.

Izvještaj Knjižnice Marina Držića za 2000. godinu. Arhiva Knjižnice Marina Držića. [interni dokument]

Izvještaj Knjižnice Marina Držića za 2002. godinu. Arhiva Knjižnice Marina Držića. [interni dokument]

Izvještaj Knjižnice Marina Držića za 2003. godinu. Arhiva Knjižnice Marina Držića. [interni dokument]

Izvještaj Knjižnice Marina Držića za 2004. godinu. Arhiva Knjižnice Marina Držića. [interni dokument]

Izvještaj Knjižnice Marina Držića za 2005. godinu. Arhiva Knjižnice Marina Držića. [interni dokument]

Izvještaj Knjižnice Marina Držića za 2006. godinu. Arhiva Knjižnice Marina Držića. [interni dokument] 
Izvještaj Knjižnice Marina Držića za 2007. godinu. Arhiva Knjižnice Marina Držića. [interni dokument]

Izvještaj Knjižnice Marina Držića za 2016. godinu. Arhiva Knjižnice Marina Držića. [interni dokument]

Izvještaj Knjižnice Marina Držića za 2017. godinu. Arhiva Knjižnice Marina Držića. [interni dokument]

Izvještaj Knjižnice Marina Držića za 2018. godinu. Arhiva Knjižnice Marina Držića. [interni dokument]

Čičko, H. Projekt „Knjižnica širom otvorenih vrata“. // Vjesnik bibliotekara Hrvatske 53, 2(2010), 10-14.

Dječji vrtić Poliklinike SUVAG. [citirano: 2018-09-21]. Dostupno na: http://www.suvag.hr/djecji-vrtic-poliklinike-suvag/.

Dječji vrtić Vladimira Nazora. Posebni program za djecu motoričkim oštećenjima (8-satni). [citirano: 2018-09-21]. Dostupno na: http://www.vrtic-vladimiranazora. zagreb.hr/default.aspx?id=57.

Europska agencija za posebne potrebe i uključivo obrazovanje - publikacije na hrvatskom. [citirano: 2018-09-09]. Dostupno na: https://www.european-agency.org/about-us.

Europska strategija za osobe s invaliditetom (2010. - 2020.). [citirano: 2018-09-09]. Dostupno na: http://www.soih.hr/pdf/europska-strategija-za-osobe-s-invaliditetom. pdf.

Globalni ciljevi održivog razvoja do 2030. [citirano: 2018-09-09]. Dostupno na: http:// odraz.hr/media/291518/globalni\%20ciljevi\%20odrzivog\%20razvoja\%20do\%20 2030_web.pdf.

Hrvatska udruga za disleksiju. Knjižnice i disleksija 2002. - 2010. [citirano: 2018-0909]. Dostupno na: http://hud.hr/knjiznice-i-disleksija/.

I ja želim čitati - Nacionalna kampanja za osobe s teškoćama čitanja i disleksijom. [citirano: 2018-09-09]. Dostupno na: https:/www.facebook.com/IJaZelimCitati/.

IFLA-ine smjernice za narodne knjižnice. 2. hrv. izd. Zagreb : Hrvatsko knjižničarsko društvo, 2011.

Ille, J. Dom, posao, nešto treće : knjižnica kao "treći prostor". // Narodne knjižnice kao treći prostor : zbornik radova / [urednice Dunja Marija Gabriel, Jelica Leščić]. Zagreb: Nacionalna i sveučilišna knjižnica, 2015. Str. 77-84.

Indeficienter. Čitaj (o) psu - R. E. A. D. 2016./2017. financijska potpora Ministarstva znanosti i obrazovanja. [citirano: 2018-09-24]. Dostupno na: http:/www.uptiv.hr/ item/citaj-o-psu-r-e-a-d-2016-2017-financijska-potpora-minstarstva-znanosti-i-obrazovanja/.

Intermountain Therapy Animal - R.E.A.D. [citirano: 2018-09-24]. Dostupno na: http:// www.therapyanimals.org/R.E.A.D.html. 
Knjižnica Savica. Knjižnica širom otvorenih vrata. [citirano: 2018-09-09]. Dostupno na: http://www.kgz.hr/hr/knjiznice/knjiznica-savica/projekti-6204/knjiznica-sirom-otvorenih-vrata-6206/6206.

Knjižnice grada Zagreba. Dječja knjižnica Marina Držića. [citirano: 2018-09-09]. Dostupno na: http://www.kgz.hr/hr/knjiznice/djecja-knjiznica-marina-drzica/59.

Knjižnice grada Zagreba. Knjižnica širom otvorenih vrata. [citirano: 2018-09-09]. Dostupno na: http://www.kgz.hr/hr/knjiznica-sirom-otvorenih-vrata-5993/5993.

Knjižnice grada Zagreba - Strateški plan 2014. - 2020. [citirano: 2018-09-09]. Dostupno na: http://www.kgz.hr/hr/o-nama/misija-vizija-i-strategija/222.

Konvencija o pravima djeteta. [citirano: 2018-09-09]. Dostupno na: https://www.unicef. hr/wp-content/uploads/2017/05/Konvencija_20o_20pravima_20djeteta_full.pdf.

Konvencija o pravima osoba s invaliditetom. // Narodne novine 6, 80(2007). [citirano: 2018-09-09]. Dostupno na: https:/narodne-novine.nn.hr/clanci/medunarodni/2007_06_6_80.html.

Logopedski centar Govorni Oblačić. [citirano: 2018-12-22]. Dostupno na: https://logopedski-centar.com/.

Osnovna škola Grigora Viteza Zagreb. Info o školi. [citirano: 2018-09-09]. Dostupno na: http://os-gviteza-zg.skole.hr/infor.

Osnovna škola Grigora Viteza Zagreb. Vijesti - Radionice u Gradskoj knjižnici „Savica“". [citirano: 2018-09-09]. Dostupno na: http://www.os-gviteza-zg.skole.hr/vijesti?news_hk $=5406 \&$ news_id $=972 \&$ mshow $=878$.

Osnovna škola Poliklinike SUVAG. [citirano: 2018-09-21]. Dostupno na: http://www. suvag.hr/osnovna-skola-poliklinike-suvag/.

Pavlek, A. Pomažu, motiviraju, usrećuju : psi pomagači u Dječjoj knjižnici Marina Držića. // HKD Novosti 68(2016). Dostupno i na: https://www.hkdrustvo.hr/hkdnovosti/ clanak/1165 [citirano: 2018-09-24].

Pričaj mi. [citirano: 2018-12-22]. Dostupno na: http://pricajmi.hr/.

Strategija borbe protiv siromaštva i socijalne isključenosti u Republici Hrvatskoj (2014. - 2020.) [citirano: 2018-09-09]. Dostupno na: https:/www.vlada.hr/UserDocsImages//Sjednice/Arhiva//148\%20-\%203.pdf.

Udruga Ozana. O nama. [citirano: 2018-09-21]. Dostupno na: http://www.udruga-ozana.hr/?page_id=2.

Udruga za pet therapy Indeficienter (UPTIV). [citirano: 2018-12-17]. Dostupno na: http://www.uptiv.hr/uptiv/.

UNICEF. Stanje djece u svijetu 2013: djeca s teškoćama u razvoju. [citirano: 2018-0909]. Dostupno na: https://www.unicef.hr/wp-content/uploads/2015/09/Djeca_s_teskocama_HR_6_13_w.pdf. 
